\title{
Synthesis, characterization, and pharmacological evaluation of novel azolo- and azinothiazinones containing 2,4-dihydroxyphenyl substituent as anticancer agents
}

\author{
Joanna Matysiak ${ }^{1} \cdot$ Małgorzata Juszczak $^{2} \cdot$ Monika M. Karpińska $^{3}$ • \\ Ewa Langner $^{2,4} \cdot$ Katarzyna Walczak $^{4} \cdot$ Marta Lemieszek $^{2} \cdot$ Alicja Skrzypek $^{1}$. \\ Wojciech Rzeski ${ }^{2,5} \cdot$ Andrzej Niewiadomy ${ }^{1,3}$
}

Received: 18 January 2015/ Accepted: 8 March 2015/Published online: 2 April 2015

(C) The Author(s) 2015. This article is published with open access at Springerlink.com

\begin{abstract}
We reported the synthesis and characterization of a series of azolo- and azino[1,3]thiazinones containing the 2,4-dihydroxyphenyl substituent. The compounds were prepared by a new one-step reaction of aryl-modified sulfinylbis[(2,4-dihydroxyphenyl)methanethione]s and the corresponding aminoazolo(azino)carboxamides. Their chemical structures were confirmed by IR, NMR: ${ }^{1} \mathrm{H},{ }^{13} \mathrm{C}$, HSQC, and EI-MS spectral data. The compounds inhibited proliferation and viability of lung cancer A549, colon cancer HT-29, and glioma C6 cells in a structure- and concentration-dependent manner. The activity of some analogues was below $10 \mu \mathrm{mol} \mathrm{dm}{ }^{-3}\left(\mathrm{IC}_{50}\right)$. Glioma C6 cells were the most sensitive to tested compounds. Generally, the derivatives were not toxic for the skin fibroblast HSF culture. Moreover, some of them exerted a protective effect on the treated normal cells. Evaluation of compound properties in silico showed that they possess significant drug-like characteristics and most of them display a low toxicity.
\end{abstract}

Joanna Matysiak

joanna.matysiak@up.lublin.pl

1 Department of Chemistry, University of Life Sciences in Lublin, Akademicka 15, 20-950 Lublin, Poland

2 Department of Medical Biology, Institute of Rural Health in Lublin, Jaczewskiego 2, 20-090 Lublin, Poland

3 Institute of Industrial Organic Chemistry in Warsaw, Annopol 6, 03-236 Warsaw, Poland

4 Department of Pharmacology, Medical University in Lublin, Chodźki 4a, 20-093 Lublin, Poland

5 Department of Virology and Immunology, Maria Curie-Skłodowska University in Lublin, Akademicka 19, 20-033 Lublin, Poland

\section{Graphical abstract}

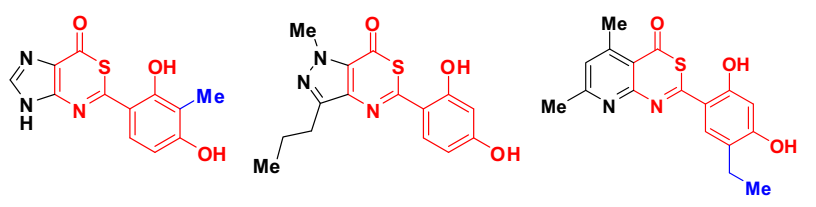

Keywords Azolothiazinones - Resorcinols · Antiproliferative activity $\cdot$ Cytotoxicity $\cdot$ ADMET

\section{Introduction}

Heterocyclic scaffolds have been a commonly used focal point for the design and development of novel antitumour agents [1-5]. A special group is the derivatives with 2,4dihydroxyphenyl moiety heat shock protein 90 (Hsp90) inhibitors, for which anticancer activity was very well documented [6]. It includes one five-membered heterocyclic ring of pyrazole [7-11], isoxazole [12], 1,2,3thiadiazole $[13,14]$ as well as two fused heterocyclic ring scaffolds of benzisoxazole [15] or 2,3-dihydrobenzoimidazol-2-one [16, 17]. It proved that the resorcinol moiety $\mathrm{OH}$ groups are critical to binding with the molecular target $[8,14,18,19]$.

One of the isoxazole resorcinol derivatives, luminespib (NVP-AUY922, VER52296), is a third-generation small-molecule Hsp90 inhibitor with potential antineoplastic activity [20, 21]. It acts via several processes to inhibit tumour growth and metastasis [22, 23]. Luminespib was entered in the I/II phase clinical trials for the patients with advanced solid tumours and multiple myeloma [24-26]. 
Scheme 1<smiles>NC(=O)c1c[nH]nc1N</smiles><smiles>CCCCCOC</smiles>

H<smiles>[R]c1cc(-c2nc3n[nH]cc3c(=O)s2)c(O)c([R])c1O</smiles><smiles>CCCc1nn(C)c(C(N)=O)c1N</smiles><smiles>[R]c1cc(-c2nc3c(CCC)nn(C)c3c(=O)s2)c(O)c([R])c1O</smiles><smiles>NC(=O)c1nc[nH]c1N</smiles>

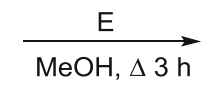<smiles>NC(=O)c1[nH]cnc1N</smiles>

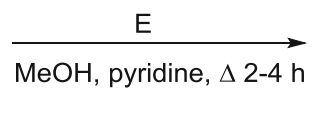

h<smiles>[R]c1cc(-c2nc3nc[nH]c3c(=O)s2)c(O)c([R])c1O</smiles><smiles>[R]c1cc(-c2nc3[nH]cnc3c(=O)s2)c(O)c([R])c1O</smiles>

3a: $R^{1}=M e, R^{2}=H$ 3b: $R^{2}=M e, R^{1}=H$ 3c: $R^{2}=E t, R^{1}=H$ 3d: $\mathrm{R}^{2}=\mathrm{Cl}, \mathrm{R}^{1}=\mathrm{H}$ 1a: $R^{1}=M e, R^{2}=H$

1b: $R^{2}=M e, R^{1}=H$

1c: $R^{2}=E t, R^{1}=H$

1d: $\mathrm{R}^{2}=\mathrm{Cl}, \mathrm{R}^{1}=\mathrm{H}$

1e: $\mathrm{R}^{1}=\mathrm{OMe}, \mathrm{R}^{2}=\mathrm{H}$

2a: $\mathrm{R}^{1}=\mathrm{R}^{2}=\mathrm{H}$

2b: $R^{1}=M e, R^{2}=H$

2c: $R^{2}=M e, R^{1}=H$

2d: $R^{2}=E t, R^{1}=H$

2e: $R^{2}=C l, R^{1}=H$ 4a: $R^{2}=M e, R^{1}=H$

4b: $R^{2}=E t, R^{1}=H$

4c: $\mathrm{R}^{2}=\mathrm{Cl}, \mathrm{R}^{1}=\mathrm{H}$<smiles>Cc1cc(C)c(C(N)=O)c(N)n1</smiles>

E:<smiles>[R]c1cc(C(=S)S(=S)C(=S)c2cc([R])c(O)c([R])c2O)c(O)c([R])c1O</smiles>

Sulfinylbis[(2,4-dihydroxyphenyl)methanethione]
$\underset{\mathrm{MeOH}, \Delta 3 \mathrm{~h}}{\stackrel{5 \mathrm{Et}-\mathrm{STB}}{\longrightarrow}}$<smiles>CCc1cc(-c2nc3nc(C)cc(C)c3c(=O)s2)c(O)cc1O</smiles>

STB: $\mathrm{R}^{1}=\mathrm{R}^{2}=\mathrm{H}$

3Me-STB: $R^{1}=M e, R^{2}=H$

5Me-STB: $R^{2}=M e, R^{1}=H$

5Et-STB: $R^{2}=E t, R^{1}=H$

5Cl-STB: $\mathrm{R}^{2}=\mathrm{Cl}, \mathrm{R}^{1}=\mathrm{H}$

3MeO-STB: $\mathrm{R}^{1}=\mathrm{OMe}, \mathrm{R}^{2}=\mathrm{H}$
Azolo-1,3-thiazin-4-ones are a group of compounds relatively poorly explored in the area of synthesis and of biological activity. Vicentini et al. described a reaction of trichloromethyl chloroformate with $N$-(1-alkyl/aryl-5-pyrazolyl)thiocarboxamides and $N$-(3-methyl-5pyrazolyl)thiobenzamide in which pyrazolo[3,4- $d][1,3]$ thiazin-4-ones or pyrazolo[1,5-c][1,3,5]thiadiazine-4-one were obtained, respectively [27]. Imidazo[4,5- $d][1,3]$ thiazine$7(3 H)$-thiones were prepared from 5(4)-substituted amino4(5)-ethoxycarbonyl-1(3H)-imidazoles with the Lawesson reagent [28]. They were designed as acyclovir analogues but exhibited weak biological properties [28, 29]. Other derivatives showed antibacterial [30] or fungicidal activity [31].
The studies carried out by our team of two fused of fiveor six-membered rings heterocycles with 2,4-dihydroxyphenyl moiety exhibited an interesting profile of anticancer properties. 4H-3,1-benzothiazin-4-ones show high activity against the human bladder cancer HCV29T, non-small cell lung carcinoma A549, breast cancer T47D, and rectal adenocarcinoma SW707 cells [32]. An antiproliferative effect of some analogues is on the level of cisplatin. Structure-activity elucidation exhibited that the presence of a chlorine atom or alkyl substituent (methyl or ethyl) in position 5 of the resorcinol ring has a beneficial effect on the potency of compounds. A similar spectrum of biological activity and analogous effects of resorcinol 
Table 1 HSQC NMR data of compounds $\mathbf{1 b}, \mathbf{1 e}$, and $\mathbf{2 c}$

\begin{tabular}{|c|c|c|c|}
\hline \multirow[t]{2}{*}{ Structure/ No } & \multirow[t]{2}{*}{ Position } & Carbon & Proton \\
\hline & & $\delta / \mathrm{ppm}$ & $\delta / \mathrm{ppm}$ \\
\hline \multirow[t]{4}{*}{$1 b$} & $\mathrm{H}-\mathrm{C}(3)$ & 132.3 & 8.4 \\
\hline & $\mathrm{H}-\mathrm{C}\left(6^{\prime}\right)$ & 129.1 & 7.5 \\
\hline & $\mathrm{H}-\mathrm{C}\left(3^{\prime}\right)$ & 102.7 & 6.5 \\
\hline & $\mathrm{CH}_{3}$ & 15.1 & 2.1 \\
\hline \multirow[t]{4}{*}{$1 \mathrm{e}$} & $\mathrm{H}-\mathrm{C}(5)$ & 133.2 & 8.2 \\
\hline & $\mathrm{H}-\mathrm{C}\left(6^{\prime}\right)$ & 127.0 & 7.7 \\
\hline & $\mathrm{H}-\mathrm{C}\left(5^{\prime}\right)$ & 108.9 & 6.5 \\
\hline & $\mathrm{OCH}_{3}$ & 60.0 & 3.8 \\
\hline \multirow[t]{7}{*}{$2 c$} & $\mathrm{H}-\mathrm{C}\left(6^{\prime}\right)$ & 128.9 & 7.4 \\
\hline & $\mathrm{H}-\mathrm{C}\left(3^{\prime}\right)$ & 102.2 & 6.3 \\
\hline & $\mathrm{NCH}_{3}$ & 39.5 & 4.13 \\
\hline & $\mathrm{CH}_{3} \mathrm{CH}_{2} \mathrm{CH}_{2-}$ & 27.4 & 2.7 \\
\hline & $\mathrm{CH}_{3}-$ & 15.0 & 2.1 \\
\hline & $\mathrm{CH}_{3} \mathrm{CH}_{2} \mathrm{CH}_{2-}$ & 21.4 & 1.7 \\
\hline & $\mathrm{CH}_{3} \mathrm{CH}_{2} \mathrm{CH}_{2}-$ & 13.5 & 0.9 \\
\hline
\end{tabular}

modification on activity were found for 1,3-thiazolo[5,4$b$ ]pyridines [33] and $1 H$-benzimidazoles [34].

In this work to develop new routes for the diversely substituted drug-like heterocyclic scaffolds, we have targeted the 5-6 and 6-6 fused-ring systems of imidazo-, pyrazolo-, and pyridothiazin-4-ones incorporating modified or unmodified 2,4-dihydroxyphenyl substituent. It was assumed that the presence of additional nitrogen atoms compared to 4H-3,1-benzothiazin-4-one can enhance interactions with a potential molecular target and intensify biological activity. Antiproliferative effect of the obtained compounds against the cells of some cancer lines and cytotoxicity against normal cells were described. Additionally, ADMET properties in silico of compounds were evaluated.

\section{Results and discussion}

\section{Chemistry}

Using in the reaction with sulfinylbis[(2,4-dihydroxyphenyl)methanethione] (STB) corresponding nucleophiles, heterocyclic carbothioamides possessing an amine group in the neighbouring position to the $\mathrm{CONH}_{2}$ group, a set of azolo- and azino[1,3]thiazin-4-ones has been obtained. Pyrazolo[3,4- $d][1,3]$ thiazin-4(2H)-one and pyrazolo[4,3d] [1,3]thiazin-7(1H)-one scaffolds were obtained from properly substituted 3-amino- $1 H$-pyrazole-4-carboxamides $\mathbf{1}$ and 4 -amino- $1 H$-pyrazole-5-carboxamides $\mathbf{2}$, respectively (Scheme 1). In the reaction with aminoimidazolecarboxamides imidazo-1,3-thiazinones $\mathbf{3}$ and $\mathbf{4}$ were formed. The application of 2-aminonicotinamide gave corresponding $4 \mathrm{H}$ pyrido[2,3- $d][1,3]$ thiazin-4-one (5). STB analogues $3 \mathrm{Me}-$ STB, 5Me-STB, 5Et-STB, 5Cl-STB, and 3MeO-STB were also applied in the synthesis of the compounds. They possessed substituted benzenediol residue and thus the compounds with modified resorcinol moiety were obtained (Scheme 1).

The reagents were applied in equimolar proportions. The reactions were performed in $\mathrm{MeOH}$ (sometimes with the addition of pyridine) under reflux (2-4 h) with moderate to good yields (70-88 \%). STB and its analogues as the initial reagents were obtained from 2,4-dihydroxybenzenecarbodithioic acid or its analogues and $\mathrm{SOCl}_{2}$ in diethyl ether according to the previously presented method [35].

The contents of $\mathrm{C}, \mathrm{H}$, and $\mathrm{N}$ were within $\pm 0.4 \%$ of the theoretical values. The mass spectra $(\mathrm{EI}, 70 \mathrm{eV})$ of all derivatives exhibited the molecular ion peak $[\mathrm{M}]^{+}$of the maximal intensity $(B=100 \%)$. The derivatives of group $\mathbf{2}$ and ethyl analogue 1c showed the peak at $\mathrm{m} / \mathrm{z}[\mathrm{M}-15]^{+}$ formed after demethylation of molecular ion.

The IR spectra of compounds exhibited a broad strong band in the range of $3462-3100 \mathrm{~cm}^{-1}$ of $v(\mathrm{O}-\mathrm{H})$. A band in the $1692-1649 \mathrm{~cm}^{-1}$ range was attributed to $\mathrm{C}=\mathrm{O}$ group. These spectra confirmed the presence of $>\mathrm{C}=\mathrm{N}-$ moiety stretching in the region around $1640-1575 \mathrm{~cm}^{-1}$. The ${ }^{13} \mathrm{C}$ NMR spectra of compounds showed signal at 172-165 ppm attributed to carbon atom of $\mathrm{C}=\mathrm{O}$ group. Proton of $\mathrm{OH}$ group was sometimes invisible (compounds $\mathbf{1 b}, \mathbf{4 c})$. CH proton of heterocyclic scaffold of all compounds appeared in the range of $8.4-8.0 \mathrm{ppm}$. NH proton is registered in the wider range of $14.0-12.5 \mathrm{ppm}$. The crosspeaks of HSQC NMR spectrum of compounds $\mathbf{1 b}, \mathbf{1 e}$, and $\mathbf{2 c}$ presented in Table 1 further support a formation of new compounds.

\section{Antiproliferative activity}

The anticancer effect of compounds was tested in nonsmall cell lung cancer A549, colon carcinoma HT-29, and glioma C6 cells. The cells were exposed to either culture medium as the control culture or the compounds in concentrations of $10,25,50$, and $100 \mu \mathrm{mol} \mathrm{dm}{ }^{-3}$. After 96-h treatment MTT assay was performed and $\mathrm{IC}_{50}$ (concentration that produced a $50 \%$ viability decrease of cells) 

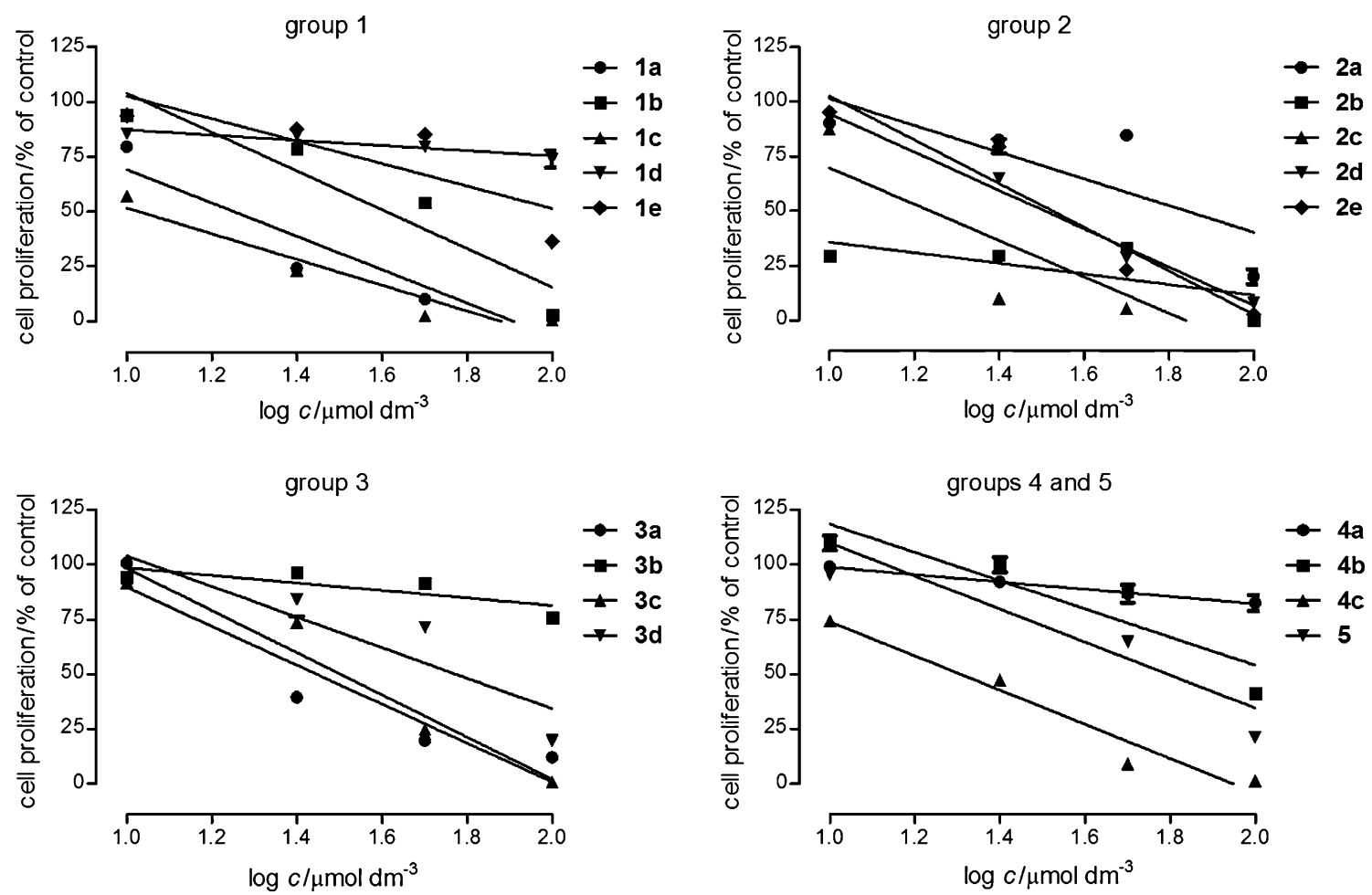

Fig. 1 The antiproliferative effect of compounds in rat glioma C6. The cells were grown in the culture medium only (control) and in the presence of tested compounds $\left(10-100 \mu \mathrm{mol} \mathrm{dm}^{-3}\right)$ for $96 \mathrm{~h}$, and the

MTT assay was performed. The data represent mean \% of control viability \pm SEM of six trials and were analyzed by means of linear regression

values for each cell line were calculated using computerized linear regression analysis of quantal log dose-probit functions [36]. Cisplatin was used as a reference drug.

The tested compounds inhibited proliferation and viability of cells in a structure- and concentration-dependent manner. Glioma C6 cells proved to be the most sensitive to compounds action (Fig. 1). The obtained $\mathrm{IC}_{50}$ values are presented in Table 2. The most active were compounds 1a and $3 \mathrm{c}$ with the $\mathrm{IC}_{50}$ values 17.2 and $8.2 \mu \mathrm{mol} \mathrm{dm}^{-3}$, respectively (cisplatin: $0.4 \mu \mathrm{mol} \mathrm{dm}{ }^{-3}$ ). The evident effect was also detected for compounds $\mathbf{1 b}, \mathbf{1 c}, \mathbf{2 c}, \mathbf{2 d}, \mathbf{3 a}$, and $\mathbf{4 c}$ (Fig. 1; Table 2).

The compounds under consideration were a little less active against A549 cells (Fig. 2). The most potent were the compounds of group $\mathbf{1}$, especially $\mathbf{1 a}\left(\mathrm{IC}_{50}=9.2\right.$ $\mu \mathrm{mol} \mathrm{dm}{ }^{-3}$ ). Higher $\mathrm{IC}_{50}$ values were calculated for $\mathbf{1 c}$ : $32.2 \mu \mathrm{mol} \mathrm{dm}{ }^{-3}$, 2a: $56.1 \mu \mathrm{mol} \mathrm{dm}{ }^{-3}$, 2d: $35.0 \mu \mathrm{mol}$ $\mathrm{dm}^{-3}$, 3a: $48.8 \mu \mathrm{mol} \mathrm{dm}{ }^{-3}$, 3c: $49.8 \mu \mathrm{mol} \mathrm{dm}{ }^{-3}, \mathbf{4 c}$ :

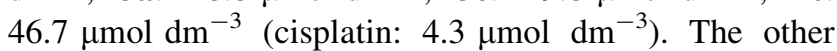
compounds were less active or inactive in the studied concentration range (they are not presented in Fig. 2).

The colon cancer HT-29 cells were the most resistance to the compounds (Fig. 3). The most active were the compounds of group 1, especially compound 1c $\left(\mathrm{IC}_{50}=20.9 \mu \mathrm{mol} \mathrm{dm}{ }^{-3}\right)$. Lower activities expressed by $\mathrm{IC}_{50}$ were calculated for the following compounds: 1a:

$102.3 \mu \mathrm{mol} \mathrm{dm}{ }^{-3}$, 1b: $109.3 \mu \mathrm{mol} \mathrm{dm}{ }^{-3}$, 2c: $157.2 \mu \mathrm{mol}$ $\mathrm{dm}^{-3}$, 3c: $75.4 \mu \mathrm{mol} \mathrm{dm}{ }^{-3}, 4 \mathbf{c}: 61.4 \mu \mathrm{mol} \mathrm{dm}{ }^{-3}$ (cisplatin: $6.0 \mu \mathrm{mol} \mathrm{dm}{ }^{-3}$ ). The other compounds inhibited proliferation of HT-29 cells in the studied concentration range to a small extent or did not show antiproliferation effect. Generally, in the tested cancer cell lines the most effective compounds seem to be $\mathbf{1 a}, \mathbf{1 c}, \mathbf{3 c}$, and $\mathbf{4 c}$.

Additionally, the influence of compounds on normal human skin fibroblast primary culture (HSF) was assessed. HSF cells were exposed to compounds (10-100 $\mu \mathrm{mol} \mathrm{dm}{ }^{-3}$ ) for $24 \mathrm{~h}$ and the level of lactic dehydrogenase (LDH) released from the damaged cells was measured (LDH method). The obtained results (Fig. 4) demonstrated that the tested derivatives were relatively low toxic for normal cells. Only compound $\mathbf{2 c}$ in all tested concentrations and $\mathbf{2 b}$ in the concentration $100 \mu \mathrm{mol} \mathrm{\textrm {dm } ^ { - 3 }}$ were highly toxic for skin fibroblasts. What is interesting is the fact that compounds 1a, 1c, 3a, 3b, 3c, and 4a induced a decrease of death cells in the culture. This may indicate protective properties of the compounds.

\section{ADMET properties in silico}

The principle goal of the in silico calculation of ADMET properties of compounds is the prediction of their in vivo biokinetics as potential drugs [37, 38]. ADMET Predictor 
Table 2 Antiproliferative activity of compounds against glioma C6 cells expressed as $\mathrm{IC}_{50}$, their molecular descriptors, and parameters of adsorption and distribution processes assumed using ADMET Predictor software

\begin{tabular}{|c|c|c|c|c|c|c|c|c|c|c|c|c|c|}
\hline No. & $\begin{array}{l}\mathrm{IC}_{50} / \\
\mu \mathrm{mol} \mathrm{dm}\end{array}$ & $\begin{array}{l}\log \\
D\end{array}$ & $\begin{array}{l}M \log \\
P\end{array}$ & $\begin{array}{l}\text { Rule of } \\
5\end{array}$ & $\mathrm{nRB}$ & $\begin{array}{l}\text { PSA/ } \\
\AA^{2}\end{array}$ & $\begin{array}{l}S / \\
\mu \mathrm{g} \mathrm{cm}^{-3}\end{array}$ & $\begin{array}{l}\text { Peff/ } \\
\mathrm{cm} \mathrm{s}^{-1} \times 10^{-4}\end{array}$ & $\begin{array}{l}\text { MDCK/ } \\
\mathrm{cm} \mathrm{s}^{-1} \times 10^{-7}\end{array}$ & $\begin{array}{l}V_{\mathrm{d}} / \\
\mathrm{dm}^{3} \mathrm{~kg}^{-1}\end{array}$ & BBB & $\begin{array}{l}\text { Log } \\
\text { BB }\end{array}$ & $\begin{array}{l}\mathrm{PPB} / \\
\%\end{array}$ \\
\hline $1 a$ & 17.2 & 2.18 & 0.95 & 0 & 1 & 99.1 & 48 & 2.47 & 140.73 & 0.7 & Low & -0.29 & 92.73 \\
\hline $1 b$ & 35.8 & 2.17 & 0.95 & 0 & 1 & 99.1 & 48 & 2.49 & 132.27 & 0.69 & Low & -0.35 & 92.85 \\
\hline 1c & 23.1 & 2.48 & 1.22 & 0 & 2 & 99.1 & 43 & 2.32 & 136.17 & 0.79 & Low & -0.27 & 93.97 \\
\hline $1 d$ & $-^{a}$ & 1.75 & 0.95 & 0 & 1 & 99.1 & 37 & 2.88 & 184.77 & 0.23 & Low & -0.55 & 98.52 \\
\hline $1 e$ & 100.8 & 1.57 & 0.19 & 0 & 2 & 108.0 & 45 & 2.94 & 109.44 & 0.55 & Low & -0.41 & 92.58 \\
\hline $2 \mathbf{a}$ & 48.9 & 2.69 & 1.34 & 0 & 3 & 88.2 & 99 & 5.18 & 172.44 & 0.82 & Low & -0.10 & 96.13 \\
\hline $2 b$ & $-^{\mathrm{a}}$ & 2.95 & 1.59 & 0 & 3 & 88.2 & 82 & 5.19 & 196.52 & 0.91 & Low & -0.10 & 96.64 \\
\hline $2 c$ & 27.1 & 2.99 & 1.59 & 0 & 3 & 88.2 & 80 & 5.21 & 186.56 & 0.90 & Low & -0.16 & 96.76 \\
\hline $2 d$ & 32.2 & 3.32 & 1.83 & 0 & 4 & 88.2 & 70 & 4.81 & 193.76 & 0.97 & Low & -0.11 & 97.32 \\
\hline $2 e$ & 31.8 & 2.94 & 1.59 & 0 & 3 & 88.2 & 74 & 5.78 & 249.87 & 0.38 & Low & -0.34 & 99.04 \\
\hline $\mathbf{3 a}$ & 33.1 & 1.42 & 0.55 & 0 & 1 & 99.1 & 51 & 1.96 & 110.01 & 1.07 & Low & -0.40 & 88.69 \\
\hline $3 \mathbf{b}$ & $-^{\mathrm{a}}$ & 1.42 & 0.55 & 0 & 1 & 99.1 & 51 & 1.98 & 103.09 & 1.06 & Low & -0.46 & 88.92 \\
\hline $3 c$ & 8.2 & 1.79 & 0.82 & 0 & 2 & 99.1 & 46 & 1.81 & 104.61 & 1.18 & Low & -0.37 & 91.06 \\
\hline $3 d$ & 53.5 & 0.91 & 0.55 & 0 & 1 & 99.1 & 42 & 2.38 & 130.67 & 0.39 & Low & -0.65 & 97.12 \\
\hline $4 a$ & $-^{\mathrm{a}}$ & 1.39 & 0.55 & 0 & 1 & 99.1 & 45 & 2.41 & 136.76 & 0.80 & Low & -0.49 & 91.39 \\
\hline $4 b$ & 89.7 & 1.76 & 0.82 & 0 & 2 & 99.1 & 40 & 2.26 & 141.31 & 0.92 & Low & -0.40 & 92.71 \\
\hline $4 c$ & 18.3 & 0.76 & 0.55 & 0 & 1 & 99.1 & 37 & 2.78 & 187.10 & 0.27 & Low & -0.69 & 97.34 \\
\hline 5 & $-{ }^{\mathrm{a}}$ & 3.35 & 2.20 & 0 & 2 & 83.3 & 35 & 4.94 & 250.10 & 1.04 & Low & -0.07 & 97.05 \\
\hline
\end{tabular}

Log $D$ octanol-water distribution coefficient, $M \log P \log P$ according to Moriguchi model, $n R B$ number of rotatable bonds, $P S A$ Polar Surface Area, $S$ water solubility, Peff human jejunal effective permeability, $M D C K$ apparent permeability for Madin-Darby Canine Kidney (MDCK) cells, $V_{d}$ volume of distribution, $B B B$ qualitative likelihood high/low of crossing the blood-brain barrier, $\log B B \log$ arithm of the brain/blood partition coefficient, $P P B$ overall fraction of a drug bound in human blood plasma (in \%)

${ }^{\text {a }}$ Value was not calculated

7.1 was applied to predict ADMET properties of the compounds under consideration [39].

An oral administration is a commonly used route for drugs and a required one for new agents. Absorption of drugs after oral administration is a very complicated process and a number of parameters for its prediction are used. Relatively simple parameters are molecular weight $(M)$, hydrophobicity: $\log D, \log P$ from different approaches [40], polar surface area (PSA), and a number of hydrogen bonding atoms (HBA, HBD). They are included in the Lipinski's rule of five [41]. The data presented in Table 2 show that all considered descriptors are in the recommended range (the number of unfulfilled rules $=0$ ). Two other parameters included in the Oprea's criteria: the number off rotatable bonds (nRB) and polar surface area (PSA) possess also the recommended values $(\mathrm{nRB}<10$; PSA $<120 \AA^{2}$ ) [37]. This shows that the compounds under consideration possess strong drug-like properties.

A more sophisticated model of absorption prediction takes into account the values of the human jejunal effective permeability (Peff) and apparent permeability (Papp) for Madin-Darby Canine Kidney (MDCK) cells. The data collected in Table 2 show that for all compounds medium permeability in the range of $103-250 \times 10^{-7} \mathrm{~cm} \mathrm{~s}^{-1}$ is assumed [42]. The estimated Peff parameter is larger than $1.8 \times 10^{-4} \mathrm{~cm} \mathrm{~s}^{-1}$. The values of both descriptors are the highest for the compounds of group $\mathbf{2}$ and for analogue $\mathbf{5}$ which are characterized by the highest lipophilicity and the lowest PSA. Good native water solubility (S) for all compounds is estimated $\left(>10 \mu \mathrm{g} \mathrm{cm}^{-3}\right)$ [43-45].

The PPB parameter was also calculated (Table 2). It describes the overall fraction of a drug bound in human blood plasma (in \%). The half of the studied compounds indicate strong binding to proteins of plasma (PPB $>95 \%$ ) and for some of them a risk associated with this property $(\mathbf{1 d}, \mathbf{2 d}, \mathbf{2 e}, \mathbf{3 d}, \mathbf{4 c}, \mathbf{5})$ is predicted. Two compounds show very weak affinity for them (PPB $<90)$ (3a, 3b). Generally, a less bounded drug can pass through cell membranes and diffuse more effectively.

Prediction of tissue distribution of a compound is another important task in the drug development. Simple descriptors such as $\log P$ and $M$ are in the optimal range for the studied compounds. The more advanced parameters were also taken into account: volume of distribution $\left(V_{\mathrm{d}}\right)$ and the descriptors describing the blood-brain barrier (BBB) penetration [46]. The compounds possess $V_{\mathrm{d}}$ in the range of $0.23-1.18 \mathrm{dm}^{3} \mathrm{~kg}^{-1}$, and the highest one was found for compounds $\mathbf{3 a}-\mathbf{3 c}$ and $\mathbf{5}$. To predict the BBB 

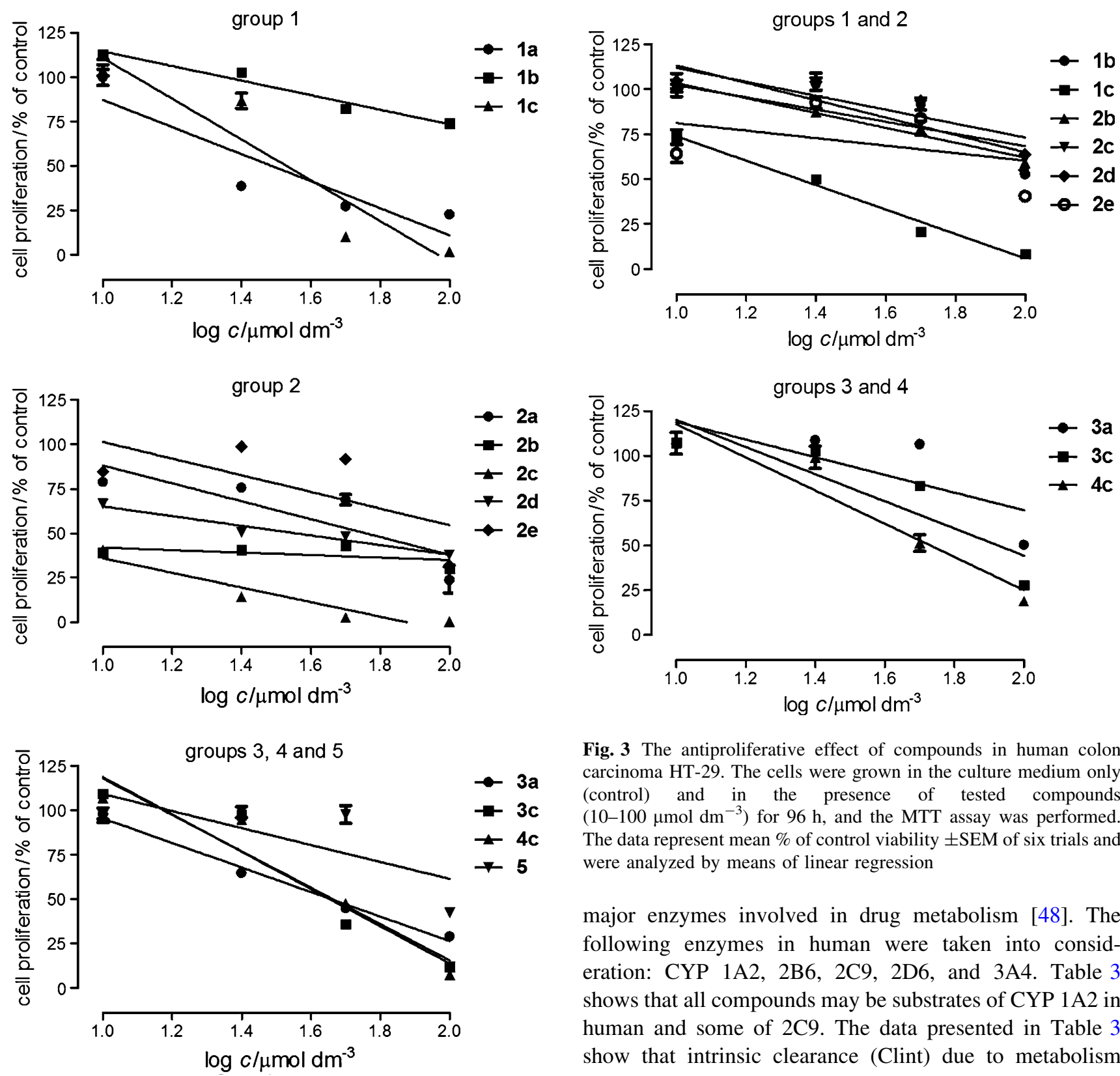

Fig. 3 The antiproliferative effect of compounds in human colon carcinoma HT-29. The cells were grown in the culture medium only (control) and in the presence of tested compounds $\left(10-100 \mu \mathrm{mol} \mathrm{dm}^{-3}\right)$ for $96 \mathrm{~h}$, and the MTT assay was performed. The data represent mean $\%$ of control viability \pm SEM of six trials and were analyzed by means of linear regression

major enzymes involved in drug metabolism [48]. The following enzymes in human were taken into consideration: CYP 1A2, 2B6, 2C9, 2D6, and 3A4. Table 3 shows that all compounds may be substrates of CYP $1 \mathrm{~A} 2$ in human and some of 2C9. The data presented in Table 3 show that intrinsic clearance (Clint) due to metabolism mediated by CYP $1 \mathrm{~A} 2$ in human is significantly lower than via 2 C9 enzymes.

Toxicity of compounds, which is a major reason for cell lung cancer A549. The cells were grown in the culture medium only (control) and in the presence of tested compounds (10-100 $\left.\mu \mathrm{mol} \mathrm{dm}^{-3}\right)$ for $96 \mathrm{~h}$, and the MTT assay was performed. The data represent mean $\%$ of control viability \pm SEM of six trials and were analyzed by means of linear regression

penetration, $\log \mathrm{BB}$ (logarithm of the brain/blood partition coefficient) and BBB filtering (qualitative likelihood high/ low of crossing the blood-brain barrier) were calculated. According to the data collected in Table 2 all studied compounds show low brain penetration $(\log \mathrm{BB}<-0.07$ ) and they rather do not across BBB [47].

Anticipating metabolism of compounds we have focused on cytochrome P450 (CYP) enzymes, which are the drug candidate failure, is also estimated. It was presented in two ADMET risk models: TOX MUT Risk and TOX Risk developed by Simulation Plus, Inc. (Table 3) [49]. TOX MUT Risk is a summary of the outputs of the ten different TOX MUT models that independently predict the mutagenicity expected for five strains of $S$. typhimurium with and without microsomal activation. The TOX Risk model consists of seven rules of different toxicities. Table 3 shows that toxicity in Tox Risk model is not predicted for compounds of group 3. A low toxicity for them is anticipated in Tox Mut Risk model. Predicted toxicity for other compounds is also relatively low and may be 

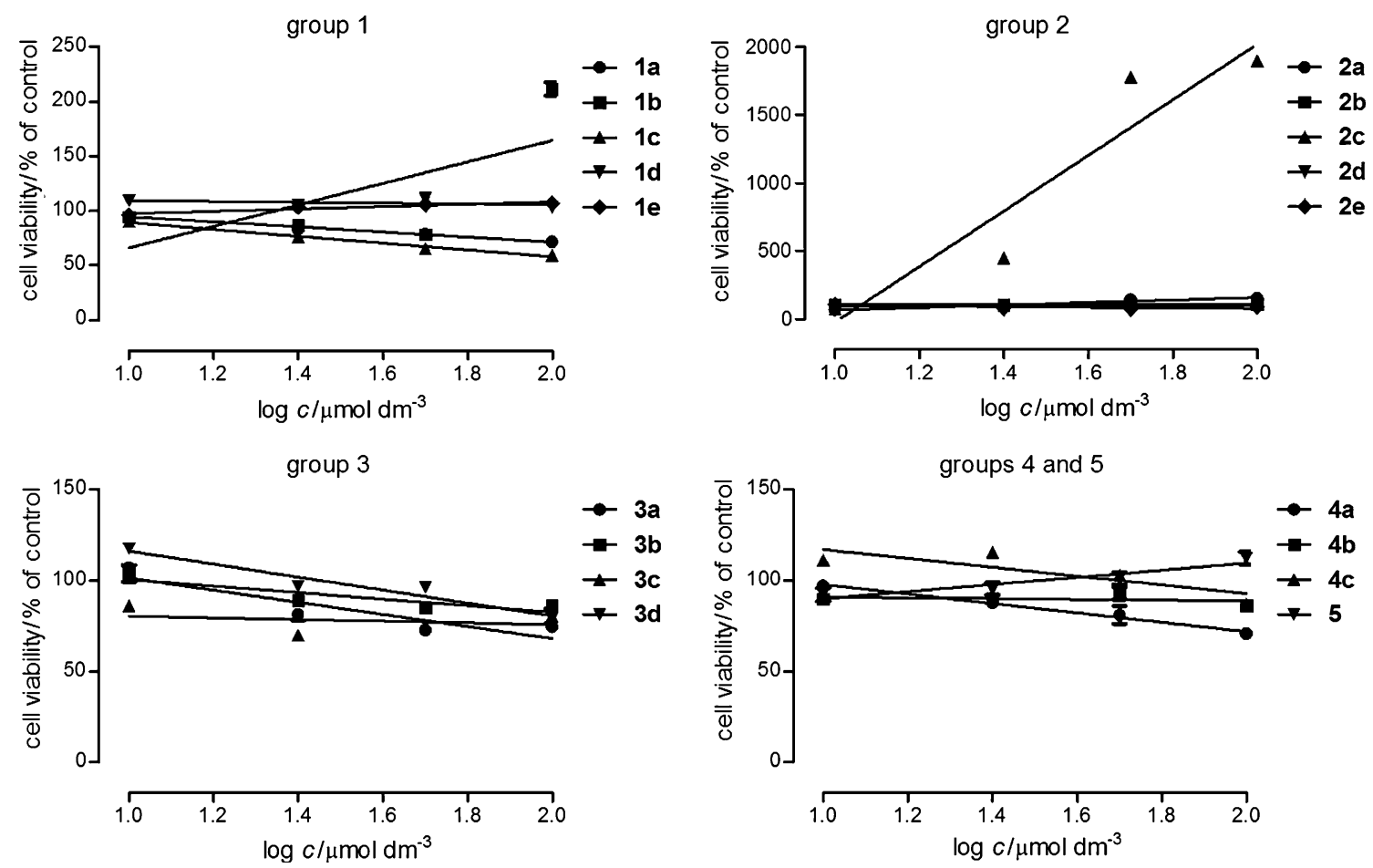

Fig. 4 Cytotoxicity of compounds in the primary culture of human skin fibroblasts HSF. The cells were grown in the culture medium only (control) and in the presence of tested compounds

(10-100 $\left.\mu \mathrm{mol} \mathrm{dm}^{-3}\right)$ for $24 \mathrm{~h}$, and the LDH assay was performed. The data represent mean $\%$ of control viability \pm SEM of 6 trials and were analyzed by means of linear regression

Table 3 Characteristics of metabolism and toxicity profile of compounds estimated by the ADMET Predictor software

\begin{tabular}{|c|c|c|c|c|c|c|c|c|c|c|c|}
\hline No. & $\begin{array}{l}\text { Substrate } \\
\text { CYP1A2/\% }\end{array}$ & $\begin{array}{l}\text { Clint CYP1 } \\
\mathrm{A} 2 / \mu \mathrm{cm}^{3} \\
\mathrm{~min}^{-1} \mathrm{mg}^{-1}\end{array}$ & $\begin{array}{l}\text { Substrate } \\
\text { CYP2C9/ \% }\end{array}$ & $\begin{array}{l}\text { Clint CYP2 } \\
\text { C9/ } \mathrm{\mu cm}^{3} \\
\mathrm{~min}^{-1} \mathrm{mg}^{-1}\end{array}$ & $\begin{array}{l}\text { TOX } \\
\text { risk }\end{array}$ & TOX code & $\begin{array}{l}\text { TOX } \\
\text { MUT } \\
\text { risk }\end{array}$ & $\begin{array}{l}\text { TOX } \\
\text { MUT } \\
\text { code }\end{array}$ & $\begin{array}{l}\text { TOX } \\
\text { Rat/mg kg }\end{array}$ & ADMET_Risk & ADMET code \\
\hline $1 a$ & Yes (63) & 4.33 & Yes (56) & 7.32 & 1.78 & $\mathrm{Xm}, \mathrm{Hp}$ & 1 & S3 & 1372.56 & 1.78 & $\mathrm{Xm}, \mathrm{Hp}$ \\
\hline $1 b$ & Yes (63) & 4.20 & Yes (56) & 3.96 & 1.92 & $\mathrm{Xm}, \mathrm{Hp}$ & 1 & S3 & 1373.27 & 1.92 & $\mathrm{Xm}, \mathrm{Hp}$ \\
\hline $1 \mathrm{c}$ & Yes (63) & 0.87 & Yes (56) & 6.27 & 1.63 & Xm, Hp & 1 & S3 & 1465.48 & 1.63 & $\mathrm{Xm}, \mathrm{Hp}$ \\
\hline 1d & Yes (57) & 3.32 & Yes (63) & 1.75 & 1.46 & $\mathrm{Xm}, \mathrm{Hp}$ & 1 & S3 & 676.78 & 2.22 & fu, Xm, Hp \\
\hline 1e & yes (63) & 2.52 & Yes (63) & 2.07 & 2.16 & $\mathrm{Xm}, \mathrm{Hp}, \mathrm{Mu}$ & 2 & $\mathrm{~m} 1, \mathrm{~S} 3$ & 1105.78 & 2.16 & $\mathrm{Xm}, \mathrm{Hp}, \mathrm{Mu}$ \\
\hline $2 a$ & Yes (60) & 4.87 & No $(60)$ & - & 3 & $\mathrm{Xm}, \mathrm{Hp}, \mathrm{Mu}$ & 2 & $\mathrm{~m} 1, \mathrm{~S} 3$ & 1342.59 & 3 & $\mathrm{Xm}, \mathrm{Hp}, \mathrm{Mu}$ \\
\hline $2 b$ & Yes (60) & 7.62 & No (64) & - & 3 & $\mathrm{Xm}, \mathrm{Hp}, \mathrm{Mu}$ & 2 & $\mathrm{~m} 1, \mathrm{~S} 3$ & 1454.44 & 3 & $\mathrm{Xm}, \mathrm{Hp}, \mathrm{Mu}$ \\
\hline $2 c$ & Yes (56) & 10.30 & No (67) & - & 3 & $\mathrm{Xm}, \mathrm{Hp}, \mathrm{Mu}$ & 2 & $\mathrm{~m} 1, \mathrm{~S} 3$ & 1449.67 & 3 & $\mathrm{Xm}, \mathrm{Hp}, \mathrm{Mu}$ \\
\hline 2d & Yes (55) & 3.26 & No (65) & - & 3 & $\mathrm{Xm}, \mathrm{Hp}, \mathrm{Mu}$ & 2 & $\mathrm{~m} 1, \mathrm{~S} 3$ & 1474.65 & 3.16 & $\mathrm{fu}, \mathrm{Xm}, \mathrm{Hp}, \mathrm{Mu}$ \\
\hline $2 e$ & Yes (58) & 18.10 & Yes (58) & 27.90 & 2 & $\mathrm{Xm}, \mathrm{Hp}$ & 1 & S3 & 776.88 & 4.06 & fu, Xm, Hp, 1A, C9 \\
\hline $3 \mathbf{a}$ & Yes (63) & 4.99 & Yes (75) & 36.20 & 0 & - & 1 & S3 & 685.69 & 1 & C9 \\
\hline $3 \mathbf{b}$ & Yes (63) & 4.99 & Yes (56) & 23.50 & 0 & - & 1 & S3 & 688.09 & 0.57 & C9 \\
\hline $3 c$ & Yes (63) & 0.89 & Yes (63) & 33.30 & 0 & - & 1 & $\mathrm{~m} 3$ & 716.96 & 1 & C9 \\
\hline 3d & Yes (58) & 6.10 & YES (75) & 15.00 & 0 & - & 1 & $\mathrm{~m} 3$ & 487.5 & 0.06 & $\mathrm{fu}$ \\
\hline $4 a$ & Yes (63) & 5.92 & Yes (63) & 18.10 & 1 & Hp & 1 & S3 & 998.28 & 1.21 & $\mathrm{Hp}, \mathrm{C} 9$ \\
\hline $4 b$ & Yes (63) & 1.40 & Yes (75) & 24.20 & 1 & Нp & 1 & $\mathrm{~m} 3$ & 1056.83 & 1.62 & Hp, C9 \\
\hline $4 c$ & Yes (57) & 5.45 & Yes (75) & 11.80 & 1 & Нp & 1 & m3 & 595.56 & 1.17 & $\mathrm{Fu}, \mathrm{Hp}$ \\
\hline 5 & Yes (63) & 0.99 & Yes (55) & 240.00 & 2 & $\mathrm{Hp}, \mathrm{Mu}$ & 2 & $\mathrm{~S} 1, \mathrm{~S} 3$ & 1315.29 & 3.03 & $\mathrm{fu}, \mathrm{Hp}, \mathrm{Mu}, \mathrm{C} 9$ \\
\hline
\end{tabular}

$X m$ TOX BRM Mouse $<35$ (carcinogenicity in chronic mouse studies), $H p$ hepatotoxicity, $M u$ TOX MUT Risk $>1, f u \%$ Unbnd $<[1,3]$ (low fraction unbound in plasma), $1 A$ MET $1 \mathrm{~A} 2 \mathrm{~km}>0.01 \mu \mathrm{mol} \mathrm{dm}{ }^{-3}$ and MET $1 \mathrm{~A} 2$ CLint $>[15,30]$, C9 MET 2C9 $\mathrm{km}>0.01 \mu \mathrm{mol} \mathrm{dm}^{-3}$ and MET 2C9 CLint $>\left[15,30 \mu \mathrm{cm}^{3} \mathrm{~min}^{-1} \mathrm{mg}^{-1}\right]$, S1 TOX MUT $97+1537=$ Positive, $S 3$ TOX MUT $102+$ wp2 = Positive, $m 3$ TOX MUT m102 + wp2 = Positive AND NOT TOX MUT $102+$ wp2 $=$ Positive 
connected with carcinogenicity in chronic rat studies $(\mathrm{Xm})$ and hepatotoxicity $(\mathrm{Hp})$ or with mutagenicity in $S$. typhimurium. The calculated acute rat toxicity values (Tox rat) show that compounds are characterized by medium toxicity in the range of $487-1474 \mathrm{mg} \mathrm{kg}^{-1}$ predicted for rats after oral administration.

ADMET Risk (global ADMET risk), a computational filter developed also by Simulations Plus Inc [49], was additionally applied. The results collected in Table 3 show that compounds of group 3 with imidazo[4,5- $d][1,3]$ thiazin-7 $(3 H)$-one skeleton, of the lowest lipophilicity in the studied group of compounds, show the best ADMET properties in the group of the studied compounds. Low risk for compounds 4 was also calculated $(<1.6)$. For comparison, ADMET Risk is larger than 6.5 for about $10 \%$ of the drugs focused WDI [49].

\section{Conclusion}

To sum up, we have obtained and characterized a series of azolothiazinones as a new group of heterocyclic compounds possessing the 2,4-dihydroxyphenyl substituent. They were prepared in the one-step novel efficient synthesis procedure. The compounds displayed diverse antiproliferative activities against cancer cell lines. The most sensitive were glioma C6 cells and the most resistant colon carcinoma HT-29. The antiproliferative potency of the most active analogues was below $10 \mu \mathrm{mol} \mathrm{dm}{ }^{-3}$. The majority of the tested compounds were not toxic for normal skin fibroblast culture. Moreover, some of them increased fibroblasts viability. Furthermore, the compounds possess strong drug-like properties and good pharmacokinetics as well as low toxicity is predicted for them in silico. In the light of the presented results, compounds $\mathbf{3 c}$ seem to be most promising. They also provide an opportunity of laying the foundation for development of more promising molecules of anticancer potency.

\section{Experimental}

Melting points were determined using a BÜCHI B-540 (Flawil, Switzerland) melting point apparatus. The elemental analysis $(\mathrm{C}, \mathrm{H}, \mathrm{N})$ was performed on Perkin-Elmer 2400. The IR spectra were measured with a Perkin-Elmer FT-IR 1725X spectrophotometer (in $\mathrm{KBr}$ ) or a Varian 670-IR FT-IR spectrometer (ATR) in the range of $600-4000 \mathrm{~cm}^{-1}$. NMR spectra were recorded in DMSO- $d_{6}$ using a Bruker DRX 500 instrument. Chemical shifts $(\delta /$ ppm) were described in relation to tetramethylsilane (TMS). The MS spectra (EI, $70 \mathrm{eV}$ ) were recorded using the apparatus AMD-604.
6-(2,4-Dihydroxy-3-methylphenyl)pyrazolo[3,4-d][1,3]thiazin-4(2H)-one $\left(\mathbf{1 a}, \mathrm{C}_{12} \mathrm{H}_{9} \mathrm{~N}_{3} \mathrm{O}_{3} \mathrm{~S}\right)$

A mixture of $0.177 \mathrm{~g} \mathrm{3}$-amino- $1 \mathrm{H}$-pyrazole-4-carboxamide (Alfa Aesar, $1.4 \mathrm{mmol}$ ) and $0.535 \mathrm{~g} 3 \mathrm{Me}-\mathrm{STB}$ $(1.4 \mathrm{mmol})$ in $7 \mathrm{~cm}^{3} \mathrm{MeOH}$ was heated to reflux for $3 \mathrm{~h}$. The hot mixture was filtered; the formed solid was crystallized from $5 \mathrm{~cm}^{3} \mathrm{MeOH}$ to give $0.28 \mathrm{~g}(73 \%)$ yellowish crystals of 1a. M.p.: $370{ }^{\circ} \mathrm{C}$ (dec.); ${ }^{1} \mathrm{H}$ NMR $\left(500 \mathrm{MHz}, \mathrm{DMSO}-d_{6}\right): \delta=12.88(\mathrm{~s}, 1 \mathrm{H}, \mathrm{NH}), 12.19$ (s, $\left.1 \mathrm{H}, \mathrm{C}\left(2^{\prime}\right)-\mathrm{OH}\right), 10.60\left(\mathrm{~s}, 1 \mathrm{H}, \mathrm{C}\left(4^{\prime}\right)-\mathrm{OH}\right), 8.28(\mathrm{~s}, 1 \mathrm{H}$, $\mathrm{C}(3)-\mathrm{H}), \quad 7.53 \quad\left(\mathrm{~d}, \quad J=8.8 \mathrm{~Hz}, \quad 1 \mathrm{H}, \quad \mathrm{C}\left(6^{\prime}\right)-\mathrm{H}\right), \quad 6.56$ $\left(\mathrm{d}, J=8.8 \mathrm{~Hz}, 1 \mathrm{H}, \mathrm{C}\left(5^{\prime}\right)-\mathrm{H}\right), 2.04\left(\mathrm{~s}, 3 \mathrm{H}, \mathrm{CH}_{3}\right) \mathrm{ppm}$; ${ }^{13} \mathrm{C}$ NMR $\left(125 \mathrm{MHz}\right.$, DMSO- $\left.d_{6}\right): \delta=164.8,161.6$, 159.0, 155.4, 136.4, 132.3, 126.4, 119.7, 111.2, 110.1, 108.2, $8.0 \mathrm{ppm}$; IR (ATR): $\bar{v}=3213(\mathrm{OH}), 3117(\mathrm{OH})$, $1661(\mathrm{C}=\mathrm{O}), 1619(\mathrm{C}=\mathrm{N}), 1567(\mathrm{C}=\mathrm{C}), 1526(\mathrm{C}=\mathrm{C})$, 1477, 1326, $1252(\mathrm{C}-\mathrm{OH}), 1102,1072,961,929$, $753 \mathrm{~cm}^{-1}$; MS $(70 \mathrm{eV}): \mathrm{m} / \mathrm{z}(\%)=275\left(\mathrm{M}^{+}, 100\right), 247$ (6), 192 (34), 167 (32), 151 (17), 150 (17), 127 (7), 126 (10), 122 (7), 120 (8), 110 (13), 94 (6), 77 (9), 65 (9).

6-(2,4-Dihydroxy-5-methylphenyl)pyrazolo[3,4-d][1,3]thiazin-4(2H)-one $\left(\mathbf{1 b}, \mathrm{C}_{12} \mathrm{H}_{9} \mathrm{~N}_{3} \mathrm{O}_{3} \mathrm{~S}\right)$

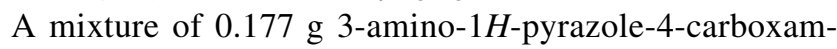
ide (Alfa Aesar, $1.4 \mathrm{mmol}$ ) and $0.535 \mathrm{~g} \mathrm{5Me-STB}$ (1.4 mmol) in $7 \mathrm{~cm}^{3} \mathrm{MeOH}$ was heated to reflux for $3 \mathrm{~h}$. The reaction mixture was left at room temperature $(24 \mathrm{~h})$ and filtered. The formed solid was combined with that obtained after the filtrate concentration. The formed solid was crystallized from $4 \mathrm{~cm}^{3} \mathrm{MeOH}$ to give $0.33 \mathrm{~g}$ $(86 \%)$ yellow crystals of $\mathbf{1 b}$. M.p.: $230{ }^{\circ} \mathrm{C}(\mathrm{dec}.) ;{ }^{1} \mathrm{H}$ NMR $\left(500 \mathrm{MHz}, \mathrm{DMSO}-d_{6}\right): \delta=13.12(\mathrm{~s}, 1 \mathrm{H}, \mathrm{NH})$, 10.59 (s, 1H, C-OH), $8.38(\mathrm{~s}, 1 \mathrm{H}, \mathrm{C}(3)-\mathrm{H}), 7.52(\mathrm{~s}, 1 \mathrm{H}$, $\left.\mathrm{C}\left(6^{\prime}\right)-\mathrm{H}\right), 6.44\left(\mathrm{~s}, 1 \mathrm{H}, \mathrm{C}\left(3^{\prime}\right)-\mathrm{H}\right), 2.09\left(\mathrm{~s}, 3 \mathrm{H}, \mathrm{CH}_{3}\right) \mathrm{ppm}$; ${ }^{13} \mathrm{C}$ NMR $\left(125 \mathrm{MHz}\right.$, DMSO- $\left.d_{6}\right): \delta=164.7,162.6$, $158.8,155.4,136.6,132.3,129.1,122.1,117.0,111.1$, 102.7, $15.1 \mathrm{ppm}$; MS $(70 \mathrm{eV}): \mathrm{m} / \mathrm{z}(\%)=276\left([\mathrm{M}+1]^{+}\right.$, 30), $275\left(\mathrm{M}^{+}, 95\right), 258$ (17), 142 (8), 217 (9), 206 (36), 167 (19), 151 (36), 150 (30), 127 (18), 126 (100), 110 (59), 109 (92), 83 (8), 80 (18), 77 (8), 69 (14), 64 (26), 52 (53), 44 (22), 43 (26), 40 (12).

6-(5-Ethyl-2,4-dihydroxyphenyl)pyrazolo[3,4-d][1,3]thiazin-4(2H)-one (1c, $\left.\mathrm{C}_{13} \mathrm{H}_{11} \mathrm{~N}_{3} \mathrm{O}_{3} \mathrm{~S}\right)$

A mixture of $0.177 \mathrm{~g} \mathrm{3}$-amino- $1 \mathrm{H}$-pyrazole-4-carboxamide (Alfa Aesar, $1.4 \mathrm{mmol})$ and $0.575 \mathrm{~g} \mathrm{5Et-STB}(1.4 \mathrm{mmol})$ in $7 \mathrm{~cm}^{3} \mathrm{MeOH}$ was heated to reflux for $2.5 \mathrm{~h}$. The hot mixture was filtered; the formed solid was crystallized from $5 \mathrm{~cm}^{3} \mathrm{MeOH}$ to give $0.33 \mathrm{~g}(82 \%)$ dark yellow crystals of 1c. M.p.: $292-293{ }^{\circ} \mathrm{C}$; ${ }^{1} \mathrm{H}$ NMR $(500 \mathrm{MHz}$, DMSO- $\left.d_{6}\right): \delta=14.24(\mathrm{~s}, 1 \mathrm{H}, \mathrm{NH}), 11.96\left(\mathrm{~s}, 1 \mathrm{H}, \mathrm{C}\left(2^{\prime}\right)-\right.$ $\mathrm{OH}), 10.54$ (s, 1H, C(4')-OH), 8.18 (s, 1H, C(3)-H), 7.49 (s, $\left.1 \mathrm{H}, \mathrm{C}\left(6^{\prime}\right)-\mathrm{H}\right), 6.44\left(\mathrm{~s}, 1 \mathrm{H}, \mathrm{C}\left(3^{\prime}\right)-\mathrm{H}\right), 2.53(\mathrm{~m}, 2 \mathrm{H}$, 
$\mathrm{CH}_{2} \mathrm{CH}_{3}$ ), 1.13 (t, $3 \mathrm{H}, J=7.48 \mathrm{~Hz}, \mathrm{CH}_{2} \mathrm{CH}_{3}$ ) ppm; ${ }^{13} \mathrm{C}$ NMR $\left(125 \mathrm{MHz}\right.$, DMSO- $\left.d_{6}\right): \delta=164.7,161.3,158.8$, $155.4,136.0,132.3,128.0,123.5,119.7,111.1,102.9$, 22.0, $14.1 \mathrm{ppm}$; IR (KBr): $\bar{v}=3471(\mathrm{OH}), 3200(\mathrm{OH})$, $3105(\mathrm{OH}), 2965(\mathrm{CH}), 1685(\mathrm{C}=\mathrm{O}), 1630(\mathrm{C}=\mathrm{N}), 1567$ $(\mathrm{C}=\mathrm{C}), 1532(\mathrm{C}=\mathrm{C}), 1493,1458,1407,1338,1267,1249$ (C-OH), 1206, 1185, 1143, 1077, 976, 944, 898, 805, $742,731 \mathrm{~cm}^{-1}$; MS (70 eV): $\mathrm{m} / \mathrm{z}(\%)=289\left(\mathrm{M}^{+}, 100\right)$, $274\left(\left[\mathrm{M}-\mathrm{CH}_{3}\right]^{+}, 93\right), 232$ (6), 220 (15), 181 (5), 165 (13), 148 (8), 127 (12), 110 (5), 91 (5), 69 (18), 65 (8), 52 (5), 45 (5), 39 (8).

6-(5-Chloro-2,4-dihydroxyphenyl)pyrazolo[3,4-d][1,3]thiazin-4(2H)-one $\left(1 \mathrm{~d}, \mathrm{C}_{11} \mathrm{H}_{6} \mathrm{ClN}_{3} \mathrm{O}_{3} \mathrm{~S}\right)$

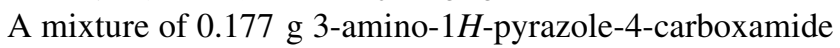
(Alfa Aesar, $1.4 \mathrm{mmol})$ and $0.593 \mathrm{~g} \mathrm{5Cl-STB}(1.4 \mathrm{mmol})$ in $7 \mathrm{~cm}^{3} \mathrm{MeOH}$ was heated to reflux for $2 \mathrm{~h}$. The hot mixture was filtered and the filtrate was concentrated. The formed solid was crystallized from $4 \mathrm{~cm}^{3} \mathrm{MeOH}$ to give $0.33 \mathrm{~g}(79 \%)$ yellow crystals of 1d. M.p.: $359-360{ }^{\circ} \mathrm{C}$; ${ }^{1} \mathrm{H}$ NMR (500 MHz, DMSO- $\left.d_{6}\right): \delta=11.81(\mathrm{~s}, 1 \mathrm{H}, \mathrm{NH})$, 11.26 (s, $\left.1 \mathrm{H}, \mathrm{C}\left(2^{\prime}\right)-\mathrm{OH}\right), 11.02\left(\mathrm{~s}, 1 \mathrm{H}, \mathrm{C}\left(4^{\prime}\right)-\mathrm{OH}\right), 8.10$ (s, 1H, C(3)-H), 7.78 (s, 1H, C(6')-H), $6.63\left(\mathrm{~s}, 1 \mathrm{H}, \mathrm{C}\left(3^{\prime}\right)-\mathrm{H}\right)$ ppm; ${ }^{13} \mathrm{C}$ NMR (125 MHz, DMSO- $\left.d_{6}\right): \delta=164.2,161.3$, $158.8,154.4,137.1,138.7,132.3,122.2,112.7,111.9$, $104.2 \mathrm{ppm}$; IR (ATR): $\bar{v}=3444(\mathrm{OH}), 3552(\mathrm{OH}), 3068$ $(\mathrm{OH}), 2846(\mathrm{CH}), 1649(\mathrm{C}=\mathrm{O}), 1584(\mathrm{C}=\mathrm{N}, \mathrm{C}=\mathrm{C}), 1521$ $(\mathrm{C}=\mathrm{C}), 1491,1445,1405,1374,1317,1292,1251(\mathrm{C}-\mathrm{OH})$, 1203, 1174, 1052, 968, 939, 870, 801, 772, 746, $728 \mathrm{~cm}^{-1}$; MS (70 eV): $m / z(\%)=295\left(\mathrm{M}^{+}, 100\right), 278(9), 267(7)$, 218 (12), 187 (33), 170 (26), 152 (7), 142 (8), 131 (6), 126 (14), 120 (8), 110 (10), 99 (7), 95 (8), 79 (4), 71 (5), 69 (18), 53 (9), 44 (6), 39 (6).

\section{6-(2,4-Dihydroxy-3-methoxyphenyl)pyrazolo[3,4-}

d] [1,3]thiazin-4(2H)-one $\left(\mathbf{1 e}, \mathrm{C}_{12} \mathrm{H}_{9} \mathrm{~N}_{3} \mathrm{O}_{4} \mathrm{~S}\right)$

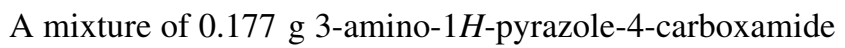
(Alfa Aesar, $1.4 \mathrm{mmol}$ ) and $0.580 \mathrm{~g} \mathrm{3MeO-STB} \mathrm{(1.4} \mathrm{m-}$ mol) in $7 \mathrm{~cm}^{3} \mathrm{MeOH}$ was heated to reflux for $3 \mathrm{~h}$. The hot mixture was filtered, and the formed solid was combined with that obtained after the filtrate concentration. The compound was crystallized from $5 \mathrm{~cm}^{3} \mathrm{MeOH}$ to give $0.29 \mathrm{~g}(71 \%)$ light yellow crystals of 1e. M.p.: 304-305 ${ }^{\circ} \mathrm{C}$; ${ }^{1} \mathrm{H}$ NMR $\left(500 \mathrm{MHz}\right.$, DMSO- $\left.d_{6}\right): \delta=12.59$ (s, 1H, NH), 11.07 (s, 1H, C(2')-OH), 10.09 (s, 1H, C(4')$\mathrm{OH}), 8.17$ (s, 1H, C(3)-H), $7.66\left(\mathrm{~d}, J=8.8 \mathrm{~Hz}, 1 \mathrm{H}, \mathrm{C}\left(6^{\prime}\right)-\right.$ $\mathrm{H}), 6.46\left(\mathrm{~d}, J=8.9 \mathrm{~Hz}, 1 \mathrm{H}, \mathrm{C}\left(5^{\prime}\right)-\mathrm{H}\right), 3.71\left(\mathrm{~s}, 3 \mathrm{H}, \mathrm{OCH}_{3}\right)$ ppm; ${ }^{13} \mathrm{C}$ NMR (125 MHz, DMSO- $\left.d_{6}\right): \delta=164.8,158.4$, $154.0,149.90,136.1,133.2,124.0,123.0,117.4,111.6$, 109.6, $60.0 \mathrm{ppm}$; MS $(70 \mathrm{eV}): \mathrm{m} / \mathrm{z}(\%)=291\left(\mathrm{M}^{+}, 100\right)$, 276 (12), 273 (25), 260 (10), 220 (17), 183 (23), 168 (13), 167 (23), 152 (12), 110 (7).
5-(2,4-Dihydroxyphenyl)-1-methyl-3-propylpyrazolo[4,3d][1,3]thiazin-7(1H)-one $\left(2 \mathrm{a}, \mathrm{C}_{15} \mathrm{H}_{15} \mathrm{~N}_{3} \mathrm{O}_{3} \mathrm{~S}\right)$

A mixture of $0.255 \mathrm{~g}$ 4-amino-1-methyl-3-propyl-1 $\mathrm{H}$-pyrazole-5-carboxamide (Sigma-Aldrich, $1.4 \mathrm{mmol}$ ) and $0.496 \mathrm{~g} \mathrm{STB}(1.4 \mathrm{mmol})$ in $7 \mathrm{~cm}^{3} \mathrm{MeOH}$ was heated to reflux for $3 \mathrm{~h}$. The reaction mixture was left at room temperature $(24 \mathrm{~h})$ and filtered. The formed solid was combined with that obtained after the filtrate concentration. The compound was crystallized from $5 \mathrm{~cm}^{3} \mathrm{MeOH}$ to give $0.36 \mathrm{~g}(87 \%)$ yellow crystals of 2a. M.p.: $268-269^{\circ} \mathrm{C}$; ${ }^{1} \mathrm{H}$ NMR (500 MHz, DMSO- $\left.d_{6}\right): \delta=12.53\left(\mathrm{~s}, 1 \mathrm{H}, \mathrm{C}\left(2^{\prime}\right)-\right.$ $\mathrm{OH}), 10.37$ (s, 1H, C(4')-OH), $7.54(\mathrm{~d}, J=8.81 \mathrm{~Hz}, 1 \mathrm{H}$, $\left.\mathrm{C}\left(6^{\prime}\right)-\mathrm{H}\right), 6.41\left(\mathrm{dd}, J=8.81,2.33 \mathrm{~Hz}, 1 \mathrm{H}, \mathrm{C}\left(5^{\prime}\right)-\mathrm{H}\right), 6.36$ $\left(\mathrm{d}, J=2.33 \mathrm{~Hz}, 1 \mathrm{H}, \mathrm{C}\left(3^{\prime}\right)-\mathrm{H}\right), 4.13\left(\mathrm{~s}, 3 \mathrm{H}, \mathrm{CH}_{3}\right), 2.77(\mathrm{t}$, $J=7.39 \mathrm{~Hz}, \quad 2 \mathrm{H}, \quad \mathrm{CH}_{2} \mathrm{CH}_{2} \mathrm{CH}_{3}$ ), $1.73 \quad$ (sextet, $\left.J=7.38 \mathrm{~Hz}, 2 \mathrm{H}, \mathrm{CH}_{2} \mathrm{CH}_{2} \mathrm{CH}_{3}\right), 0.94(\mathrm{t}, J=7.38 \mathrm{~Hz}$, $\left.3 \mathrm{H}, \mathrm{CH}_{2} \mathrm{CH}_{2} \mathrm{CH}_{3}\right) \mathrm{ppm} ;{ }^{13} \mathrm{C}$ NMR (125 MHz, DMSO- $\left.d_{6}\right)$ : $\delta=172.4,163.2,162.4,160.0,146.2,136.9,129.9,122.4$, 111.0, 108.6, 103.1, 39.0, 27.1, 21.5, 13.7 ppm; IR (ATR): $\bar{v}=3280(\mathrm{OH}), 2940(\mathrm{CH}), 1690(\mathrm{C}=\mathrm{O}), 1629(\mathrm{C}=\mathrm{N})$, $1587(\mathrm{C}=\mathrm{C}), 1529(\mathrm{C}=\mathrm{C}), 1485,1442,1335,1246(\mathrm{C}-\mathrm{OH})$, $1217,1179,1135,1106,1031,973,878,769 \mathrm{~cm}^{-1}$; MS $(70 \mathrm{eV}): \mathrm{m} / \mathrm{z}(\%)=317\left(\mathrm{M}^{+}, 100\right), 302(21), 289(75), 280$ (13), 256 (9), 242 (15), 214 (20), 173 (21), 153 (10), 119 (7), 69 (6), 42 (8).

5-(2,4-Dihydroxy-3-methylphenyl)-1-methyl-3-propylpyrazolo[4,3-d][1,3]thiazin-7(1H)-one $\left(\mathbf{2 b}, \mathrm{C}_{16} \mathrm{H}_{17} \mathrm{~N}_{3} \mathrm{O}_{3} \mathrm{~S}\right)$

A mixture of $0.255 \mathrm{~g}$ 4-amino-1-methyl-3-propyl-1 $H$-pyrazole-5-carboxamide (Sigma-Aldrich, $1.4 \mathrm{mmol}$ ) and $0.535 \mathrm{~g}$ 3Me-STB $(1.4 \mathrm{mmol})$ in $7 \mathrm{~cm}^{3} \mathrm{MeOH}$ was heated to reflux for $2.5 \mathrm{~h}$. The reaction mixture was left at room temperature $(24 \mathrm{~h})$ and filtered. The formed solid was crystallized from $5 \mathrm{~cm}^{3} \mathrm{MeOH}$ to give $0.40 \mathrm{~g}(86 \%)$ yellowish crystals of 2b. M.p.: $269-270{ }^{\circ} \mathrm{C} ;{ }^{1} \mathrm{H}$ NMR $\left(500 \mathrm{MHz}, \mathrm{DMSO}-d_{6}\right): \delta=13.18\left(\mathrm{~s}, 1 \mathrm{H}, \mathrm{C}\left(2^{\prime}\right)-\mathrm{OH}\right)$, 10.37 (s, $\left.1 \mathrm{H}, \mathrm{C}\left(4^{\prime}\right)-\mathrm{OH}\right), 7.41(\mathrm{~d}, J=8.80 \mathrm{~Hz}, 1 \mathrm{H}$, $\left.\mathrm{C}\left(6^{\prime}\right)-\mathrm{H}\right), 6.51\left(\mathrm{~d}, J=8.79 \mathrm{~Hz}, 1 \mathrm{H}, \mathrm{C}\left(5^{\prime}\right)-\mathrm{H}\right), 4.14(\mathrm{~s}$, $\left.3 \mathrm{H}, \mathrm{CH}_{3}\right), 2.80\left(\mathrm{t}, J=7.32 \mathrm{~Hz}, 2 \mathrm{H}, \mathrm{CH}_{2} \mathrm{CH}_{2} \mathrm{CH}_{3}\right), 2.02$ (s, $3 \mathrm{H}, \mathrm{CH}_{3}$ ), 1.75 (sextet, $J=7.33 \mathrm{~Hz}, 2 \mathrm{H}, \mathrm{CH}_{2} \mathrm{CH}_{2} \mathrm{CH}_{3}$ ), 0.96 (t, $\left.J=7.29 \mathrm{~Hz}, 3 \mathrm{H}, \mathrm{CH}_{2} \mathrm{CH}_{2} \mathrm{CH}_{3}\right) \mathrm{ppm} ;{ }^{13} \mathrm{C} \mathrm{NMR}$ $\left(125 \mathrm{MHz}, \mathrm{DMSO}-d_{6}\right): \delta=172.1,164.2,160.3,158.3$, 145.9, 136.7, 126.0, 122.6, 111.1, 110.1, 107.8, 39.5, 27.4, 21.4, 13.7, $8.0 \mathrm{ppm}$; IR (ATR): $\bar{v}=3185(\mathrm{OH}), 2965$ $(\mathrm{CH}), 1686(\mathrm{C}=\mathrm{O}), 1620(\mathrm{C}=\mathrm{N}), 1538(\mathrm{C}=\mathrm{C}), 1481,1433$, 1309, $1266(\mathrm{C}-\mathrm{OH}), 1236,1096,1066,1032,901,798$, $778 \mathrm{~cm}^{-1}$; MS $(70 \mathrm{eV}): \mathrm{m} / \mathrm{z}(\%)=331\left(\mathrm{M}^{+}, 100\right), 303$ (62), 302 (10), 256 (40), 187 (13), 167 (6), 77 (6).

5-(2,4-Dihydroxy-5-methylphenyl)-1-methyl-3-propylpyrazolo[4,3-d][1,3]thiazin-7(1H)-one $\left(2 \mathbf{c}, \mathrm{C}_{16} \mathrm{H}_{17} \mathrm{~N}_{3} \mathrm{O}_{3} \mathrm{~S}\right)$

A mixture of $0.255 \mathrm{~g}$ 4-amino-1-methyl-3-propyl-1 $\mathrm{H}$-pyrazole-5-carboxamide (Sigma-Aldrich, $1.4 \mathrm{mmol}$ ) and 
$0.535 \mathrm{~g} 5 \mathrm{Me}-\mathrm{STB}(1.4 \mathrm{mmol})$ in $7 \mathrm{~cm}^{3} \mathrm{MeOH}$ was heated to reflux for $3 \mathrm{~h}$. The reaction mixture was left at room temperature $(24 \mathrm{~h})$ and filtered. The obtained solid was combined with that obtained after the filtrate concentration. The formed solid was crystallized from $5 \mathrm{~cm}^{3} \mathrm{MeOH}$ to give $0.37 \mathrm{~g}(79 \%)$ pink crystals of 2c. M.p.: $260-261{ }^{\circ} \mathrm{C}$; ${ }^{1} \mathrm{H}$ NMR $\left(500 \mathrm{MHz}, \mathrm{DMSO}-d_{6}\right): \delta=12.45\left(\mathrm{~s}, 1 \mathrm{H}, \mathrm{C}\left(2^{\prime}\right)-\right.$ $\mathrm{OH}), 10.40$ (s, 1H, C(4')-OH), 7.37 (s, 1H, C $\left.\left(6^{\prime}\right)-\mathrm{H}\right), 6.30$ $\left(\mathrm{s}, 1 \mathrm{H}, \mathrm{C}\left(3^{\prime}\right)-\mathrm{H}\right), 4.13\left(\mathrm{~s}, 3 \mathrm{H}, \mathrm{CH}_{3}\right), 2.74(\mathrm{t}, J=7.44 \mathrm{~Hz}$, $2 \mathrm{H}, \mathrm{CH}_{2} \mathrm{CH}_{2} \mathrm{CH}_{3}$ ), 2.07 (s, 3H, $\mathrm{CH}_{3}$ ), 1.73 (sextet, $\left.J=7.41 \mathrm{~Hz}, 2 \mathrm{H}, \mathrm{CH}_{2} \mathrm{CH}_{2} \mathrm{CH}_{3}\right), 0.95(\mathrm{t}, J=7.40 \mathrm{~Hz}$, $3 \mathrm{H}, \mathrm{CH}_{2} \mathrm{CH}_{2} \mathrm{CH}_{3}$ ) ppm; ${ }^{13} \mathrm{C}$ NMR (125 MHz, DMSO- $\left.d_{6}\right)$ : $\delta=172.2,163.2,160.6,158.2,146.0,136.9,129.0,122.2$, 116.9, 110.2, 102.5, $39.5\left(\mathrm{NCH}_{3}\right), 27.1,21.4,15.1\left(\mathrm{CH}_{3}\right)$, 13.8 ppm; IR (ATR): $\bar{v}=3166(\mathrm{OH}), 2956(\mathrm{CH}), 1679$ $(\mathrm{C}=\mathrm{O}), 1630(\mathrm{C}=\mathrm{N}), 1529(\mathrm{C}=\mathrm{C}), 1450,1408,1382,1266$ $(\mathrm{C}-\mathrm{OH}), 1244,1137,1031,895,871,788 \mathrm{~cm}^{-1} ; \mathrm{MS}$ $(70 \mathrm{eV}): \mathrm{m} / \mathrm{z}(\%)=331\left(\mathrm{M}^{+}, 100\right), 316(13), 303(51), 302$ (8), 256 (11), 228 (15), 187 (13).

5-(5-Ethyl-2,4-dihydroxyphenyl)-1-methyl-3-propylpyrazolo[4,3-d][1,3]thiazin-7(1H)-one $\left(2 \mathbf{d}, \mathrm{C}_{17} \mathrm{H}_{19} \mathrm{~N}_{3} \mathrm{O}_{3} \mathrm{~S}\right)$

A mixture of $0.255 \mathrm{~g}$ 4-amino-1-methyl-3-propyl-1 $H$-pyrazole-5-carboxamide (Sigma-Aldrich, $1.4 \mathrm{mmol}$ ) and $0.575 \mathrm{~g}$ 5Et-STB $(1.4 \mathrm{mmol})$ in $7 \mathrm{~cm}^{3} \mathrm{MeOH}$ was heated to reflux for $3.5 \mathrm{~h}$. The reaction mixture was left at room temperature $(24 \mathrm{~h})$ and filtered. The formed solid was crystallized from $5 \mathrm{~cm}^{3} \mathrm{MeOH}$ to give $0.40 \mathrm{~g}(82 \%)$ yellow crystals of 2d. M.p.: $269-270{ }^{\circ} \mathrm{C}$; ${ }^{1} \mathrm{H} \mathrm{NMR}$ $\left(500 \mathrm{MHz}, \mathrm{DMSO}-d_{6}\right): \delta=12.44$ (s, $\left.1 \mathrm{H}, \mathrm{C}\left(2^{\prime}\right)-\mathrm{OH}\right)$, 10.40 (s, 1H, C( $\left.\left.4^{\prime}\right)-\mathrm{OH}\right), 7.36$ (s, 1H, C $\left.\left(6^{\prime}\right)-\mathrm{H}\right), 6.40$ (s, $\left.1 \mathrm{H}, \mathrm{C}\left(3^{\prime}\right)-\mathrm{H}\right), 4.13\left(\mathrm{~s}, 3 \mathrm{H}, \mathrm{CH}_{3}\right), 2.78(\mathrm{t}, J=7.40 \mathrm{~Hz}, 2 \mathrm{H}$, $\left.\mathrm{CH}_{2} \mathrm{CH}_{2} \mathrm{CH}_{3}\right), 2.50\left(\mathrm{t}, \mathrm{J}=7.47 \mathrm{~Hz}, 2 \mathrm{H}, \mathrm{CH}_{2} \mathrm{CH}_{3}\right), 1.73$ (sextet, $\left.J=7.4 \mathrm{~Hz}, \quad 2 \mathrm{H}, \quad \mathrm{CH}_{2} \mathrm{CH}_{2} \mathrm{CH}_{3}\right), \quad 1.13 \quad(\mathrm{t}$, $\left.J=7.47 \mathrm{~Hz}, 3 \mathrm{H}, \mathrm{CH}_{2} \mathrm{CH}_{3}\right), 0.95(\mathrm{t}, J=7.34 \mathrm{~Hz}, 3 \mathrm{H}$, $\left.\mathrm{CH}_{2} \mathrm{CH}_{2} \mathrm{CH}_{3}\right)$ ppm; ${ }^{13} \mathrm{C}$ NMR (125 MHz, DMSO-d $d_{6}$ : $\delta=172.2,163.5,160.5,158.2,146.1,136.0,127.8$, 123.4, 119.1, 110.8, 102.8, $39.5\left(\mathrm{NCH}_{3}\right), 27.1,22.0$ $\left(\mathrm{CH}_{3} \mathrm{CH}_{2}\right), 21.5,14.1\left(\mathrm{CH}_{3} \mathrm{CH}_{2}\right), 13.7 \mathrm{ppm}$; IR (ATR): $\bar{v}=3319(\mathrm{OH}), 2968(\mathrm{CH}), 1678(\mathrm{C}=\mathrm{O}), 1628(\mathrm{C}=\mathrm{N})$, $1526(\mathrm{C}=\mathrm{C}), 1408,1339,1238(\mathrm{C}-\mathrm{OH}), 1226,1126,1032$, 898, 829, 794, $702 \mathrm{~cm}^{-1}$; MS (70 eV): $\mathrm{m} / \mathrm{z}(\%)=345$ $\left(\mathrm{M}^{+}, 100\right), 330\left(\left[\mathrm{M}-\mathrm{CH}_{3}\right]^{+}, 75\right), 317$ (35), 270 (24), 201 (8), 151 (4), 148 (5), 69 (7).

5-(5-Chloro-2,4-dihydroxyphenyl)-1-methyl-3-propylpyrazolo[4,3-d][1,3]thiazin-7(1H)-one $\left(2 \mathbf{e}, \mathrm{C}_{15} \mathrm{H}_{14} \mathrm{ClN}_{3} \mathrm{O}_{3} \mathrm{~S}\right)$ A mixture of $0.255 \mathrm{~g}$ 4-amino-1-methyl-3-propyl-1 $H$-pyrazole-5-carboxamide (Sigma-Aldrich, $1.4 \mathrm{mmol}$ ) and $0.593 \mathrm{~g} 5 \mathrm{Cl}-\mathrm{STB}$ (1.4 mmol) in $7 \mathrm{~cm}^{3} \mathrm{MeOH}$ was heated to reflux for $3.5 \mathrm{~h}$. The reaction mixture was left at room temperature $(24 \mathrm{~h})$ and filtered. The formed solid was crystallized from $5 \mathrm{~cm}^{3} \mathrm{MeOH}$ to give $0.41 \mathrm{~g}(84 \%)$ yellowish crystals of 2e. M.p.: $287-290{ }^{\circ} \mathrm{C}$; ${ }^{1} \mathrm{H}$ NMR $\left(500 \mathrm{MHz}, \mathrm{DMSO}-d_{6}\right): \delta=12.53$ (s, 1H, C $\left.\left(2^{\prime}\right)-\mathrm{OH}\right)$, 12.13 (s, 1H, C( $\left.\left.4^{\prime}\right)-\mathrm{OH}\right), 7.66\left(\mathrm{~s}, 1 \mathrm{H}, \mathrm{C}\left(6^{\prime}\right)-\mathrm{H}\right), 6.60$ (s, $\left.1 \mathrm{H}, \mathrm{C}\left(3^{\prime}\right)-\mathrm{H}\right), 4.15\left(\mathrm{~s}, 3 \mathrm{H}, \mathrm{CH}_{3}\right), 2.81(\mathrm{t}, J=7.39 \mathrm{~Hz}, 2 \mathrm{H}$, $\mathrm{CH}_{2} \mathrm{CH}_{2} \mathrm{CH}_{3}$ ), 1.73 (sextet, $\mathrm{J}=7.36 \mathrm{~Hz}, 2 \mathrm{H}, \mathrm{CH}_{2} \mathrm{CH}_{2}$ $\left.\mathrm{CH}_{3}\right), 0.95\left(\mathrm{t}, J=7.40 \mathrm{~Hz}, 3 \mathrm{H}, \mathrm{CH}_{2} \mathrm{CH}_{2} \mathrm{CH}_{3}\right) \mathrm{ppm}$; ${ }^{13} \mathrm{C}$ NMR $\quad\left(125 \mathrm{MHz}, \quad \mathrm{DMSO}-d_{6}\right): \quad \delta=172.8, \quad 161.2$, $157.8,157.3,146.7,137.1,128.7,122.2,112.7,111.9$, 104.2, $40.1\left(\mathrm{NCH}_{3}\right), 27.1,21.5,13.7 \mathrm{ppm}$; IR (ATR): $\bar{v}=3364(\mathrm{OH}), 2967(\mathrm{CH}), 2845(\mathrm{CH}), 1692(\mathrm{C}=\mathrm{O}), 1628$ $(\mathrm{C}=\mathrm{N}), 1587(\mathrm{C}=\mathrm{C}), 1536(\mathrm{C}=\mathrm{C}), 1496,1442,1413,1391$, 1263, 1242, 1211, 1192, 1091, 1050, 1032, 974, 891, 870, 850, 805, 762, $737 \mathrm{~cm}^{-1}$; MS $(70 \mathrm{eV}): \mathrm{m} / \mathrm{z}(\%)=351$ $\left(\mathrm{M}^{+}, 100\right), 323$ (76), 290 (7), 276 (9), 248 (13), 207 (17), 187 (7), 153 (5), 126 (4), 82 (6), 69 (9), 42 (10).

5-(2,4-Dihydroxy-3-methylphenyl)imidazo[4,5-d][1,3]thiazin-7(3H)-one $\left(3 \mathbf{a}, \mathrm{C}_{12} \mathrm{H}_{9} \mathrm{~N}_{3} \mathrm{O}_{3} \mathrm{~S}\right)$

A mixture of $0.252 \mathrm{~g}$ 5-amino- $1 \mathrm{H}$-imidazole-4-carboxamide (Acros Organics, $2 \mathrm{mmol}$ ) and $0.764 \mathrm{~g}$ 3Me-STB ( $2 \mathrm{mmol}$ ) in $10 \mathrm{~cm}^{3} \mathrm{MeOH}$ was heated to reflux for $3 \mathrm{~h}$. The reaction mixture was left at room temperature $(24 \mathrm{~h})$ and filtered. The formed solid was crystallized from $5 \mathrm{~cm}^{3}$ $\mathrm{MeOH}$ to give $0.37 \mathrm{~g}(69 \%)$ light brown crystals of $\mathbf{3 a}$. M.p.: $\quad>410{ }^{\circ} \mathrm{C} ; \quad{ }^{1} \mathrm{H}$ NMR $\quad\left(500 \mathrm{MHz}, \quad\right.$ DMSO- $\left.d_{6}\right)$ : $\delta=10.43(\mathrm{~s}, 1 \mathrm{H}, \mathrm{NH}), 10.19\left(\mathrm{~s}, 1 \mathrm{H}, \mathrm{C}\left(2^{\prime}\right)-\mathrm{OH}\right), 10.16$ (s, 1H, C(4')-OH), $8.26(\mathrm{~s}, 1 \mathrm{H}, \mathrm{C}(2)-\mathrm{H}), 7.37(\mathrm{~s}, 1 \mathrm{H}$, $\left.\mathrm{C}\left(6^{\prime}\right)-\mathrm{H}\right), 6.43\left(\mathrm{~d}, J=8.90 \mathrm{~Hz}, 1 \mathrm{H}, \mathrm{C}\left(5^{\prime}\right)-\mathrm{H}\right), 2.03(\mathrm{~s}, 3 \mathrm{H}$, $\left.\mathrm{CH}_{3}\right) \mathrm{ppm} ;{ }^{13} \mathrm{C}$ NMR (125 MHz, DMSO-d 6 ): $\delta=161.7$, 158.6, 154.7, 136.9. 134.9, 133.4, 126.1, 122.6, 111.2, 110.1, 107.4, 8.0 ppm; MS (70 eV): $m / z(\%)=275\left(\mathrm{M}^{+}\right.$, 100), 274 (5), 259 (5), 192 (20), 167 (26), 151 (25), 110 (5), 68 (16).

\section{5-(2,4-Dihydroxy-5-methylphenyl)imidazo[4,5-d][1,3]thi-} azin-7(3H)-one $\left(3 \mathbf{b}, \mathrm{C}_{12} \mathrm{H}_{9} \mathrm{~N}_{3} \mathrm{O}_{3} \mathrm{~S}\right)$

A mixture of $0.252 \mathrm{~g}$ 5-amino- $1 \mathrm{H}$-imidazole-4-carboxamide (Acros Organics, $2 \mathrm{mmol}$ ) and $0.764 \mathrm{~g} \mathrm{5Me-STB}$ ( $2 \mathrm{mmol}$ ) in $10 \mathrm{~cm}^{3} \mathrm{MeOH}$ was heated to reflux for $3 \mathrm{~h}$. The reaction mixture was left at room temperature $(24 \mathrm{~h})$ and filtered. The formed solid was crystallized from $5 \mathrm{~cm}^{3}$ $\mathrm{MeOH}$ to give $0.39 \mathrm{~g}(71 \%)$ yellow crystals of 3b. M.p.: 361-362 ${ }^{\circ} \mathrm{C}$; ${ }^{1} \mathrm{H}$ NMR (500 MHz, DMSO- $\left.d_{6}\right): \delta=13.42$ (s, 1H, NH), $12.54\left(\mathrm{~s}, 1 \mathrm{H}, \mathrm{C}\left(2^{\prime}\right)-\mathrm{OH}\right), 10.25\left(\mathrm{~s}, 1 \mathrm{H}, \mathrm{C}\left(4^{\prime}\right)\right.$ $\mathrm{OH}), 8.10$ (s, 1H, C(2)-H), $7.40\left(\mathrm{~s}, 1 \mathrm{H}, \mathrm{C}\left(6^{\prime}\right)-\mathrm{H}\right), 6.45$ (s, $\left.1 \mathrm{H}, \quad \mathrm{C}\left(3^{\prime}\right)-\mathrm{H}\right), 2.06\left(\mathrm{~s}, \quad 3 \mathrm{H}, \mathrm{CH}_{3}\right) \mathrm{ppm} ;{ }^{13} \mathrm{C} \quad \mathrm{NMR}$ $\left(125 \mathrm{MHz}, \mathrm{DMSO}-d_{6}\right): \delta=162.0,158.0,154.7,136.9$, 134.9, 133.4, 128.8, 122.2, 116.9, 110.4, 102.4, 15.1 ppm; MS (70 eV): $m / z(\%)=275\left(\mathrm{M}^{+}, 100\right), 259(13), 248(6)$, 215 (9), 206 (16), 167 (62), 151 (16), 110 (6), 69 (5).

5-(5-Ethyl-2,4-dihydroxyphenyl)imidazo[4,5-d][1,3]thiazin-7(3H)-one $\left(3 \mathbf{c}, \mathrm{C}_{13} \mathrm{H}_{11} \mathrm{~N}_{3} \mathrm{O}_{3} \mathrm{~S}\right)$

A mixture of $0.252 \mathrm{~g}$ 5-amino- $1 \mathrm{H}$-imidazole-4-carboxamide (Acros Organics, $2 \mathrm{mmol}$ ) and $0.821 \mathrm{~g}$ 5Et-STB 
( $2 \mathrm{mmol}$ ) in $10 \mathrm{~cm}^{3} \mathrm{MeOH}$ was heated to reflux for $3 \mathrm{~h}$. The reaction mixture was left at room temperature $(24 \mathrm{~h})$ and filtered. The formed solid was crystallized from $5 \mathrm{~cm}^{3}$ $\mathrm{MeOH}$ to give $0.33 \mathrm{~g}$ ( $88 \%$ ) light brown crystals of 3c. M.p.: $334{ }^{\circ} \mathrm{C}$ (dec.); ${ }^{1} \mathrm{H}$ NMR $\left(500 \mathrm{MHz}\right.$, DMSO- $\left.d_{6}\right)$ : $\delta=13.96(\mathrm{~s}, 1 \mathrm{H}, \mathrm{NH}), 12.67\left(\mathrm{~s}, 1 \mathrm{H}, \mathrm{C}\left(2^{\prime}\right)-\mathrm{OH}\right), 10.45$ (s, $\left.1 \mathrm{H}, \mathrm{C}\left(4^{\prime}\right)-\mathrm{OH}\right), 8.40(\mathrm{~s}, 1 \mathrm{H}, \mathrm{C}(2)-\mathrm{H}), 7.46\left(\mathrm{~s}, 1 \mathrm{H}, \mathrm{C}\left(6^{\prime}\right)-\right.$ $\mathrm{H}), 6.45\left(\mathrm{~s}, 1 \mathrm{H}, \mathrm{C}\left(3^{\prime}\right)-\mathrm{H}\right), 2.53\left(\mathrm{~m}, 2 \mathrm{H}, \mathrm{CH}_{2} \mathrm{CH}_{3}\right), 1.11(\mathrm{t}$, $\left.3 \mathrm{H}, J=7.48 \mathrm{~Hz}, \mathrm{CH}_{2} \mathrm{CH}_{3}\right)$ ppm; ${ }^{13} \mathrm{C}$ NMR $(125 \mathrm{MHz}$, DMSO- $\left.d_{6}\right): \delta=162.5,160.0,157.0,134.7,133.4,128.9$, $127.3,123.3,119.1,110.4,102.4,22.3,14.0 \mathrm{ppm}$; MS $(70 \mathrm{eV}): \mathrm{m} / \mathrm{z}(\%)=289\left(\mathrm{M}^{+}, 100\right), 275(15), 274(92), 246$ (6), 220 (9), 214 (22), 181 (17), 165 (7), 137 (7), 120 (6), 79 (6), 57 (7).

\section{5-(5-Chloro-2,4-dihydroxyphenyl)imidazo[4,5-d][1,3]thi-} azin- $7(3 \mathrm{H})$-one $\left(\mathbf{3 d}, \mathrm{C}_{11} \mathrm{H}_{6} \mathrm{ClN}_{3} \mathrm{O}_{3} \mathrm{~S}\right)$

A mixture of $0.252 \mathrm{~g} \mathrm{5}$-amino- $1 \mathrm{H}$-imidazole-4-carboxamide (Acros Organics, $2 \mathrm{mmol}$ ) and $0.874 \mathrm{~g}$ 5Cl-STB $(2 \mathrm{mmol})$ in $10 \mathrm{~cm}^{3} \mathrm{MeOH}$ was heated to reflux for $3 \mathrm{~h}$. The reaction mixture was left at room temperature $(24 \mathrm{~h})$ and filtered. The formed solid was crystallized from $5 \mathrm{~cm}^{3}$ $\mathrm{MeOH}$ to give $0.47 \mathrm{~g}(80 \%)$ brown crystals of 3d. M.p.: $>410{ }^{\circ} \mathrm{C} ;{ }^{1} \mathrm{H}$ NMR $\left(500 \mathrm{MHz}\right.$, DMSO- $\left.d_{6}\right): \delta=13.49$ (s, broad, $\left.2 \mathrm{H}, \mathrm{NH}, \mathrm{C}\left(2^{\prime}\right)-\mathrm{OH}\right), 10.45$ (s, $\left.1 \mathrm{H}, \mathrm{C}\left(4^{\prime}\right)-\mathrm{OH}\right), 8.34$ (s, 1H, C(2)-H), 7.54 (s, 1H, C(6')-H), 6.66 (s, 1H, C( $\left.3^{\prime}\right)-$ H) ppm; ${ }^{13} \mathrm{C}$ NMR $\left(125 \mathrm{MHz}\right.$, DMSO- $\left.d_{6}\right): \delta=165.0$, $157.5,154.7,134.8,133.4,130.3,128.8,120.5,117.4$, 111.7, $103.4 \mathrm{ppm}$; MS $(70 \mathrm{eV}): \mathrm{m} / \mathrm{z}(\%)=295\left(\mathrm{M}^{+}, 100\right)$, 261 (14), 260 (15), 235 (13), 187 (19), 165 (7), 171 (14), 153 (7), 69 (7).

\section{5-(2,4-Dihydroxy-5-methylphenyl)imidazo[4,5-d][1,3]thi-} azin-7(1H)-one $\left(\mathbf{4 a}, \mathrm{C}_{12} \mathrm{H}_{9} \mathrm{~N}_{3} \mathrm{O}_{3} \mathrm{~S}\right)$

A mixture of $0.189 \mathrm{~g} \mathrm{4}$-amino- $1 \mathrm{H}$-imidazole-5-carboxamide (Fluorochem, $1.5 \mathrm{mmol}$ ) and $0.574 \mathrm{~g}$ 5Me-STB $(1.5 \mathrm{mmol})$ in $7 \mathrm{~cm}^{3} \mathrm{MeOH}$ and $0.7 \mathrm{~cm}^{3}$ pyridine was heated to reflux for $3 \mathrm{~h}$. The reaction mixture was left at room temperature $(24 \mathrm{~h})$ and filtered. The obtained solid was combined with that prepared after the filtrate concentration. The formed solid was crystallized from $5 \mathrm{~cm}^{3}$ $\mathrm{MeOH}$ to give $0.29 \mathrm{~g}(70 \%)$ brown crystals of 4a. M.p.: 362-363 ${ }^{\circ} \mathrm{C} ;{ }^{1} \mathrm{H}$ NMR (500 MHz, DMSO- $\left.d_{6}\right): \delta=13.42$ (s, 1H, NH), 11.54 (s, 1H, C(2')-OH), 10.29 (s, 1H, C(4')$\mathrm{OH}), 8.11(\mathrm{~s}, 1 \mathrm{H}, \mathrm{C}(2)-\mathrm{H}), 7.50\left(\mathrm{~s}, 1 \mathrm{H}, \mathrm{C}\left(6^{\prime}\right)-\mathrm{H}\right), 6.45$ (s, $\left.1 \mathrm{H}, \quad \mathrm{C}\left(3^{\prime}\right)-\mathrm{H}\right), 2.06\left(\mathrm{~s}, 3 \mathrm{H}, \mathrm{CH}_{3}\right) \mathrm{ppm} ;{ }^{13} \mathrm{C} \quad \mathrm{NMR}$ $\left(125 \mathrm{MHz}, \mathrm{DMSO}-d_{6}\right): \delta=164.5,161.1,157.8,154.0$, 136.5, 133.5, 130.0, 125.5, 120.1, 116.5, 115.2, $15.1 \mathrm{ppm}$; IR (ATR): $\bar{v}=3338,3186(\mathrm{OH}), 1670(\mathrm{C}=\mathrm{O}), 1616$ $(\mathrm{C}=\mathrm{N}), 1599(\mathrm{C}=\mathrm{C}), 1466,1419,1347,1263(\mathrm{C}-\mathrm{OH})$, 1151, 1112, 1031, 820, 770, $742 \mathrm{~cm}^{-1}$; MS $(70 \mathrm{eV}): \mathrm{m} /$ $z(\%)=275\left(\mathrm{M}^{+}, 100\right), 206(23), 167$ (22), 151 (31), 126 (5), 109 (5), 69 (7).
5-(5-Ethyl-2,4-dihydroxyphenyl)imidazo[4,5-d][1,3]thiazine- $7(1 \mathrm{H})$-one $\left(\mathbf{4 b}, \mathrm{C}_{13} \mathrm{H}_{11} \mathrm{~N}_{3} \mathrm{O}_{3} \mathrm{~S}\right)$

A mixture of $0.189 \mathrm{~g}$ 4-amino- $1 \mathrm{H}$-imidazole-5-carboxamide (Fluorochem, $1.5 \mathrm{mmol}$ ) and $0.616 \mathrm{~g}$ 5Et-STB $(1.5 \mathrm{mmol})$ in $7 \mathrm{~cm}^{3} \mathrm{MeOH}$ was heated to reflux for $2 \mathrm{~h}$. The hot mixture was filtered. The formed solid was crystallized from $4 \mathrm{~cm}^{3}$ $\mathrm{MeOH}$ to give $0.33 \mathrm{~g}(77 \%)$ light brown crystals of $4 \mathbf{b}$. M.p.: 239-240 ${ }^{\circ} \mathrm{C} ;{ }^{1} \mathrm{H}$ NMR (500 MHz, DMSO- $\left.d_{6}\right): \delta=13.46$ (s, $1 \mathrm{H}, \mathrm{NH}), 11.53\left(\mathrm{~s}, 1 \mathrm{H}, \mathrm{C}\left(2^{\prime}\right)-\mathrm{OH}\right), 10.22\left(\mathrm{~s}, 1 \mathrm{H}, \mathrm{C}\left(4^{\prime}\right)-\mathrm{OH}\right)$, $8.13(\mathrm{~s}, 1 \mathrm{H}, \mathrm{C}(2)-\mathrm{H}), 7.47\left(\mathrm{~s}, 1 \mathrm{H}, \mathrm{C}\left(6^{\prime}\right)-\mathrm{H}\right), 6.45\left(\mathrm{~s}, 1 \mathrm{H}, \mathrm{C}\left(3^{\prime}\right)-\right.$ $\mathrm{H}), 2.74\left(\mathrm{q}, J=7.43 \mathrm{~Hz}, 2 \mathrm{H}, \mathrm{CH}_{2} \mathrm{CH}_{3}\right), 1.10(\mathrm{t}, J=7.40 \mathrm{~Hz}$, $\left.3 \mathrm{H}, \mathrm{CH}_{2} \mathrm{CH}_{3}\right)$ ppm; ${ }^{13} \mathrm{C}$ NMR (125 MHz, DMSO- $\left.d_{6}\right)$ : $\delta=164.2,161.2,154.0,136.5,136.1,134.4,127.4,123.4$, 119.1, 110.8, 102.8, 22.1, $14.2 \mathrm{ppm}$; IR (ATR): $\bar{v}=3467$ $(\mathrm{OH}), 3218(\mathrm{OH}), 2968(\mathrm{CH}), 2837(\mathrm{CH}), 1675(\mathrm{C}=\mathrm{O}), 1620$ $(\mathrm{C}=\mathrm{N}), 1599(\mathrm{C}=\mathrm{C}), 1443,1379,1237(\mathrm{C}=\mathrm{OH}), 1136,1118$, $1032,830,794,767,716 \mathrm{~cm}^{-1}$; MS $(70 \mathrm{eV}): \mathrm{m} / \mathrm{z}(\%)=289$ $\left(\mathrm{M}^{+}, 94\right), 274\left(\left[\mathrm{M}-\mathrm{CH}_{3}\right]^{+}, 100\right), 246(7), 220(10), 214(21)$, 204 (6), 181 (15), 165 (15), 148 (7), 123 (9), 109 (7), 77 (9), 69 (15), 43 (9), 39 (8).

5-(5-Chloro-2,4-dihydroxyphenyl)imidazo[4,5-d][1,3]thiazine- $7(1 \mathrm{H})$-one $\left(\mathbf{4 c}, \mathrm{C}_{11} \mathrm{H}_{6} \mathrm{ClN}_{3} \mathrm{O}_{3} \mathrm{~S}\right)$

A mixture of $0.189 \mathrm{~g} 4$-amino- $1 H$-imidazole-5-carboxamide (Fluorochem, $1.5 \mathrm{mmol}$ ) and $0.635 \mathrm{~g} \quad 5 \mathrm{Cl}-\mathrm{STB}$ $(1.5 \mathrm{mmol})$ in $7 \mathrm{~cm}^{3} \mathrm{MeOH}$ and $0.7 \mathrm{~cm}^{3}$ pyridine was heated to reflux for $3 \mathrm{~h}$. The reaction mixture was left at room temperature $(24 \mathrm{~h})$ and filtered. The formed solid was crystallized from $5 \mathrm{~cm}^{3} \mathrm{MeOH}$ to give $0.31 \mathrm{~g}(71 \%)$ brown crystals of 4c. M.p.: $>410{ }^{\circ} \mathrm{C}$ (dec.); ${ }^{1} \mathrm{H}$ NMR $\left(500 \mathrm{MHz}, \mathrm{DMSO}-d_{6}\right): \delta=11.06(\mathrm{~s}, 1 \mathrm{H}, \mathrm{OH}), 8.35$ (s, 1H, C(2)-H), 7.50 (s, 1H, C(6')-H), 6.64 (s, 1H, C( $\left.\left.3^{\prime}\right)-\mathrm{H}\right)$ ppm; ${ }^{13} \mathrm{C}$ NMR $\left(125 \mathrm{MHz}\right.$, DMSO- $\left.d_{6}\right): \delta=164.5,161.1$, $157.0,136.5,136.5,134.8,129.6,124.5,112.8,111.9$, 103.3 ppm; IR (ATR): $\bar{v}=3343,3200(\mathrm{OH}), 2842(\mathrm{CH})$, $1592(\mathrm{C}=\mathrm{O}), 1545(\mathrm{C}=\mathrm{C}), 1529(\mathrm{C}=\mathrm{C}), 1447,1418,1350$, $1305,1250,1175,1111,1031,810,708 \mathrm{~cm}^{-1}$; MS $(70 \mathrm{eV}): \mathrm{m} / \mathrm{z}(\%)=295\left(\mathrm{M}^{+}, 100\right), 267$ (6), $260(24)$, 235 (16), 207 (7), 187 (18), 180 (11), 173 (8), 171 (24), 160 (10), 153 (8), 144 (13), 142 (12), 126 (18), 109 (13), 79 (11), 69 (18), 64 (23), 52 (10), 39 (6).

2-(5-Ethyl-2,4-dihydroxyphenyl)-5,7-dimethyl-4H-pyrido[2,3-d][1,3]thiazine-4-one $\left(5, \mathrm{C}_{17} \mathrm{H}_{16} \mathrm{~N}_{2} \mathrm{O}_{3} \mathrm{~S}\right)$

A mixture of $0.248 \mathrm{~g}$ 2-amino-4,6-dimethylnicotinamide (Sigma-Aldrich, $1.5 \mathrm{mmol}$ ) and $0.616 \mathrm{~g} \mathrm{5Et-STB}(1.5 \mathrm{~m}-$ mol) in $10 \mathrm{~cm}^{3} \mathrm{MeOH}$ was heated to reflux for $3 \mathrm{~h}$. The hot mixture was filtered. The filtrate was concentrated and the formed solid was crystallized from $4 \mathrm{~cm}^{3} \mathrm{MeOH}$ to give $0.34 \mathrm{~g}(68 \%)$ orange crystals of 5. M.p.: $>410{ }^{\circ} \mathrm{C}$; ${ }^{1} \mathrm{H}$ NMR $\left(500 \mathrm{MHz}\right.$, DMSO- $\left.d_{6}\right): \delta=14.27$ (s, $1 \mathrm{H}, \mathrm{C}\left(2^{\prime}\right)-$ $\mathrm{OH}), 10.29$ (s, 1H, C(4')-OH), 8.06 (s, 1H, C(2)-H), 7.89 (s, $\left.1 \mathrm{H}, \mathrm{C}\left(6^{\prime}\right)-\mathrm{H}\right), 6.45\left(\mathrm{~s}, 1 \mathrm{H}, \mathrm{C}\left(3^{\prime}\right)-\mathrm{H}\right), 2.53(\mathrm{q}, J=7.48 \mathrm{~Hz}$, 
$\left.2 \mathrm{H}, \mathrm{CH}_{2} \mathrm{CH}_{3}\right), 2.39\left(\mathrm{~s}, 3 \mathrm{H}, \mathrm{CH}_{3}\right), 2.31\left(\mathrm{~s}, 3 \mathrm{H}, \mathrm{CH}_{3}\right), 1.13(\mathrm{t}$, $\left.J=7.48 \mathrm{~Hz}, 3 \mathrm{H}, \mathrm{CH}_{2} \mathrm{CH}_{3}\right) \mathrm{ppm} ;{ }^{13} \mathrm{C} \mathrm{NMR}(125 \mathrm{MHz}$, DMSO- $\left.d_{6}\right): \delta=168.8,153.3,152.2,147.8,136.2,136.0$, 128.1, 128.7, 123.1, 123.2, 119.7, 111.2, 102.2, 22.0, 21.0, 19.0, $14.1 \mathrm{ppm}$; IR (ATR): $\bar{v}=3299,3131(\mathrm{OH}), 2967$ $(\mathrm{CH}), 1650(\mathrm{C}=\mathrm{O}), 1600(\mathrm{C}=\mathrm{N}), 1556(\mathrm{C}=\mathrm{C}), 1491,1430$, 1390, 1349, 1278, 1249 (C-OH), 1217, 1140, 1032, 900, 874, 732, $680 \mathrm{~cm}^{-1}$; MS $(70 \mathrm{eV}): \mathrm{m} / z(\%)=328\left(\mathrm{M}^{+}\right.$, 100), 311 (21), 296 (12), 285 (32), 283 (7), 181 (13), 165 (28), 164 (11), 148 (28), 121 (16), 119 (10), 105 (7), 80 (9), 77 (22), 69 (23), 65 (12), 64 (12), 40 (8), 39 (12).

\section{Cell cultures}

Human non-small cell lung cancer A549 (Cat. No. 86012804), human colon adenocarcinoma HT-29 (Cat. No. 91072201), rat glioma C6 (Cat. No. 92090409) cell lines were obtained from the PHE Culture Collections (Public Health England Culture Collections, Porton Down, Salisbury, UK). Primary culture of normal human skin fibroblasts (HSF) was obtained by the outgrowth technique from skin explants of young persons in our laboratory. The cells were kept in the following culture media purchased from Sigma (Sigma Chemicals, St. Louis, MO, USA): A549-3:1 mixture of DMEM and Nutrient mixture F-12 Ham; C6 and HSF-DMEM, HT-29_-1:1 mixture of DMEM and Nutrient mixture F-12 Ham. All media were supplemented with $10 \%$ FBS (Sigma), penicillin (100 $\mathrm{U} \mathrm{cm}^{-3}$, Sigma) and streptomycin $\left(100 \mu \mathrm{g} \mathrm{cm}^{-3}\right.$, Sigma). The cultures were kept at $37{ }^{\circ} \mathrm{C}$ in a humidified atmosphere of $95 \%$ air and $5 \% \mathrm{CO}_{2}$.

\section{Proliferation assay}

Cancer cells were plated on 96-well microplates at a density of $1 \times 10^{4}$ (A549), $3 \times 10^{4}$ (HT-29), and $0.5 \times 10^{4}$ (C6) cells $\mathrm{cm}^{-3}$. Next day, the culture medium was removed and the cells exposed to serial dilutions of compounds $\left(10,25,50\right.$, and $\left.100 \mu \mathrm{mol} \mathrm{dm}{ }^{-3}\right)$ in a fresh medium. Cell proliferation was assessed after $96 \mathrm{~h}$ using the MTT method in which the yellow tetrazolium salt (MTT) is metabolized by viable cells to purple formazan crystals. The cancer cells were incubated for 3-4 h with MTT solution $\left(5 \mathrm{mg} \mathrm{cm}^{-3}\right)$. Formazan crystals were solubilized overnight in the SDS buffer (10\% SDS in $0.01 \mathrm{~mol} \mathrm{dm}^{-3} \mathrm{HCl}$ ) and the product quantified spectrophotometrically by measuring absorbance at the $570 \mathrm{~nm}$ wavelength using a Elx800 microplate reader (BIO-TEK, Highland Park, Winooski, Vermont, USA).

\section{Cytotoxicity assay}

Skin fibroblasts HSF were plated on 96-well microplates at a density of $1 \times 10^{5}$ cells $\mathrm{cm}^{-3}$. The following day, the culture medium was removed and the cells exposed to serial dilutions of compounds $(10,25,50$, and $100 \mu \mathrm{mol} \mathrm{dm}^{-3}$ ) diluted in a fresh culture medium with a reduced amount of FBS $(2 \%)$. Cytotoxicity was detected after $24 \mathrm{~h}$ with the use In Vitro Toxicology Assay Kit, Lactic Dehydrogenase based (Sigma). The assay is based on the reduction of NAD by the action of lactic dehydrogenase (LDH) released from damaged cells. The resulting $\mathrm{NADH}$ is utilized in the stoichiometric conversion of a tetrazolium dye. The resulting coloured compound is measured spectrophotometrically. The test was carried out according to the kit procedure. The colour product was quantified spectrophotometrically at $450 \mathrm{~nm}$ wavelength using an Elx800 microplate reader.

\section{Statistical analysis}

Statistical analyses were performed with the use of GraphPad Prism 5 (GraphPad Software, Inc., La Jolla, CA, USA) and Microsoft Office Excel 2007 computer software.

\section{In silico ADMET evaluation}

In silico ADMET evaluation of compounds was performed by ADMET Predictor version 7.1 [39]. Structures of the compounds were saved in the mol format using Chem Office software. Then, mol files of compounds were uploaded into the ADMET predictor software for further evaluation. All descriptors were estimated at $\mathrm{pH}$ 7.4.

Acknowledgement This project was financed from the funds of the National Science Centre in Poland allocated on the basis of the decision number DEC-2011/01/B/NZ4/05005.

Open Access This article is distributed under the terms of the Creative Commons Attribution License which permits any use, distribution, and reproduction in any medium, provided the original author(s) and the source are credited.

\section{References}

1. Abdel-Mohsen HT, Ragab FAF, Ramla MM, El Diwani HI (2010) Eur J Med Chem 45:2336

2. Demirayak S, Abu Mohsen U, Karaburun AC (2002) Eur J Med Chem 37:255

3. Huang ST, Hsei IJ, Chen CP (2006) Bioorg Med Chem 14:6106

4. Jauhari PK, Bhavani A, Varalwar S, Singhal K, Raj P (2008) Med Chem Res 17:412

5. Yang X-H, Wen Q, Zhao T-T, Sun J, Li X, Xing M, Lu X, Zhu H-L (2012) Bioorg Med Chem 20:1181

6. Kitson RRA, Moody CJ (2013) J Org Chem 78:5117

7. McDonald E, Jones K, Brough PA, Drysdale MJ, Workman P (2006) Curr Top Med Chem 6:1193

8. Cheung KMJ, Matthews TP, James K, Rowlands MG, Boxall KJ, Sharp SY, Maloney A, Roe SM, Prodromou C, Pearl LH, Aherne GW, McDonald E, Workman P (2005) Bioorg Med Chem Lett $15: 3338$ 
9. Smith NF, Hayes A, James K, Nutley BP, McDonald E, Henley A, Dymock B, Drysdale MJ, Raynaud FI, Workman P (2006) Mol Cancer Ther 5:1628

10. Brough PA, Barril X, Beswick M, Dymock BW, Drysdale MJ, Wright L, Grant K, Massey A, Surgenor A, Workman P (2005) Bioorg Med Chem Lett 15:5197

11. Sharp SY, Boxall K, Rowlands M, Prodromou C, Roe SM, Maloney A, Powers M, Clarke PA, Box G, Sanderson S, Patterson L, Matthews TP, Cheung KMJ, Ball K, Hayes A, Raynaud F, Marais R, Pearl L, Eccles S, Aherne W, McDonald E, Workman P (2007) Cancer Res 67:2206

12. Brough PA, Aherne W, Barril X, Borgognoni J, Boxall K, Cansfield JE, Cheung KMJ, Collins I, Davies NGM, Drysdale MJ, Dymock B, Eccles SA, Finch H, Fink A, Hayes A, Howes R, Hubbard RE, James K, Jordan AM, Lockie A, Martins V, Massey A, Matthews TP, McDonald E, Northfield CJ, Pearl LH, Prodromou C, Ray S, Raynaud FI, Roughley SD, Sharp SY, Surgenor A, Walmsley DL, Webb P, Wood M, Workman P, Wrightt L (2008) J Med Chem 51:196

13. Cikotiene I, Kazlauskas E, Matuliene J, Michailoviene V, Torresan J, Jachno J, Matulis D (2009) Bioorg Med Chem Lett 19:1089

14. Taddei M, Ferrini S, Giannotti L, Corsi M, Manetti F, Giannini G, Vesci L, Milazzo FM, Alloatti D, Guglielmi MB, Castorina M, Cervoni ML, Barbarino M, Fodera R, Carollo V, Pisano C, Armaroli S, Cabri W (2014) J Med Chem 57:2258

15. Gopalsamy A, Shi M, Golas J, Vogan E, Jacob J, Johnson M, Lee F, Nilakantan R, Petersen R, Svenson K, Chopra R, Tam MS, Wen Y, Ellingboe J, Arndt K, Boschelli F (2008) J Med Chem $51: 373$

16. Jensen MR, Schoepfer J, Radimerski T, Massey A, Guy CT, Brueggen J, Quadt C, Buckler A, Cozens R, Drysdale MJ, GarciaEcheverria C, Chene P (2008) Breast Cancer Res 10:R33

17. Lundgren K, Zhang H, Brekken J, Huser N, Powell RE, Timple N, Busch DJ, Neely L, Sensintaffar JL, Yang YC, McKenzie A, Friedman J, Scannevin R, Kamal A, Hong K, Kasibhatla SR, Boehm MF, Burrows FJ (2009) Mol Cancer Ther 8:921

18. Feldman RI, Mintzer B, Zhu D, Wu JM, Biroc SL, Yuan S, Emayan K, Chang Z, Chen D, Arnaiz DO, Bryant J, Ge XS, Whitlow M, Adler M, Polokoff MA, Li W-W, Ferrer M, Sato T, Gu J-M, Shen J, Tseng J-L, Dinter H, Buckman B (2009) Chem Biol Drug Des 74:43

19. Clevenger RC, Blagg BSJ (2004) Org Lett 6:4459

20. Stuehmer T, Zoellinger A, Siegmund D, Chatterjee M, Grella E, Knop S, Kortuem M, Unzicker C, Jensen MR, Quadt C, Chene P, Schoepfer J, Garcia-Echeverria C, Einsele H, Wajant H, Bargou RC (2008) Leukemia 22:1604

21. Gaykema SBM, Schroder CP, Vitfell-Rasmussen J, Chua S, Munnink THO, Brouwers AH, Bongaerts AHH, Akimov M, Fernandez-Ibarra C, Lub-de Hooge MN, de Vries EGE, Swanton C, Banerji U (2014) Clin Cancer Res 20:3945

22. Eccles SA, Massey A, Raynaud FI, Sharp SY, Box G, Valenti M, Patterson L, Brandon AdH, Gowan S, Boxall F, Aherne W, Rowlands M, Hayes A, Martins V, Urban F, Boxall K, Prodromou C, Pearl L, James K, Matthews TP, Cheung K-M, Kalusa A, Jones K, McDonald E, Barril X, Brough PA, Cansfield JE, Dymock B, Drysdale MJ, Finch H, Howes R, Hubbard RE, Surgenor A, Webb P, Wood M, Wright L, Workman P (2008) Cancer Res $68: 2850$
23. Eccles SA, Sharp SY, Raynaud FI, Valenti M, Patterson L, Gowan S, Boxall K, Aherne W, Rowlands M, Hayes A, Martins V, Urban F, Prodromou C, Pearl L, James K, Matthews TP, Cheung K-M, Kalusa A, Jones K, McDonald E, Brough PA, Massey A, Dymock B, Drysdale M, Workman P (2007) Mol Cancer Ther 6:3522S

24. Sharp SY, Prodromou C, Boxall K, Powers MV, Holmes JL, Box G, Matthews TP, Cheung K-MJ, Kalusa A, Janmes K, Janmes K, Hayes A, Hardcastle A, Dymock B, Brough PA, Barril X, Cansfield JE, Wright L, Surgenor A, Foloppe N, Hubbard RE, Aherne W, Pearl L, Jones K, McDonald E, Raynaud F, Eccles S, Drysdale M, Workman P (2007) Mol Cancer Ther 6:1198

25. Davenport EL, Zeisig A, Aronson LI, Moore HE, Hockley S, Gonzalez D, Smith EM, Powers MV, Sharp SY, Workman P, Morgan GJ, Davies FE (2010) Leukemia 24:1804

26. Sessa C, Shapiro GI, Bhalla KN, Britten C, Jacks KS, Mita M, Papadimitrakopoulou V, Pluard T, Samuel TA, Akimov M, Quadt C, Fernandez-Ibarra C, Lu H, Bailey S, Chica S, Banerji U (2013) Clin Cancer Res 19:3671

27. Vicentini CB, Veronese AC, Guarneri M, Manfrini M, Giori P, Guccione S (1994) J Heterocycl Chem 31:1477

28. Kaneko C, Hara S, Matsumoto H, Takeuchi T, Mori T, Ikeda K, Mizuno Y (1991) Chem Pharm Bull 39:871

29. Hara S, Kaneko C, Matsumoto H, Nishino T, Takeuchi T, Mori T, Mizuno Y, Ikeda K (1992) Nucleos Nucleot 11:571

30. Salama MA, Almotabacani LA (2004) Phosphorus Sulfur Silicon Relat Elem 179:305

31. Vicentini CB, Forlani G, Manfrini M, Romagnoli C, Mares D (2002) J Agr Food Chem 50:4839

32. Niewiadomy A, Matysiak J, Karpińska MM (2011) Arch Pharm 344:224

33. Matysiak J, Karpińska MM, Niewiadomy A, Wietrzyk J, Kłopotowska D (2012) Chem Biodivers 9:48

34. Karpińska MM, Matysiak J, Niewiadomy A, Wietrzyk J, Klopotowska D (2012) Monatsh Chem 143:269

35. Matysiak J, Niewiadomy A (2006) Synth Commun 36:1621

36. Litchfield JT, Wilcoxon F (1949) J Pharmacol Exp Ther 96:99

37. Oprea TI, Gottfries J, Sherbukhin V, Svensson P, Kuhler TC (2000) J Mol Graph Model 18:512

38. Hassan SF, Rashid U, Ansari FL, Ul-Haq Z (2013) J Mol Graph Model 45:202

39. ADMET Predictor ver. 7.1 (2014) Simulations Plus, Inc, Lancaster, CA, USA

40. Moriguchi I, Hirono S, Nakagome I, Hirano H (1994) Chem Pharm Bull 42:976

41. Lipinski CA, Lombardo F, Dominy BW, Feeney PJ (1997) Adv Drug Deliver Rev 23:3

42. Irvine JD, Takahashi L, Lockhart K, Cheong J, Tolan JW, Selick HE, Grove JR (1999) J Pharm Sci 88:28

43. Di L, Kerns EH, Carter GT (2009) Curr Pharm Design 15:2184

44. Jorgensen WL, Duffy EM (2000) Bioorg Med Chem Lett 10:1155

45. Kerns EH, Di L, Carter GT (2008) Curr Drug Metab 9:845

46. Poulin P, Schoenlein K, Theil FP (2001) J Pharm Sci 90:436

47. Ma XL, Chen C, Yang J (2005) Acta Pharmacol Sin 26:500

48. Guengerich FP (2008) Chem Res Toxicol 21:70

49. Admet predictor ${ }^{\mathrm{TM}}$, ver. 7.1. (2014) User manual, Admet property estimation and model building. Simulations Plus, Inc, Lancaster, CA, USA 